(1) Nordregio

\title{
Skills supply and governance in the Bothnian Arc cross-border region
}

By Alberto Giacometti \& Alex Cuadrado

NORDREGIO REPORT 2020:10

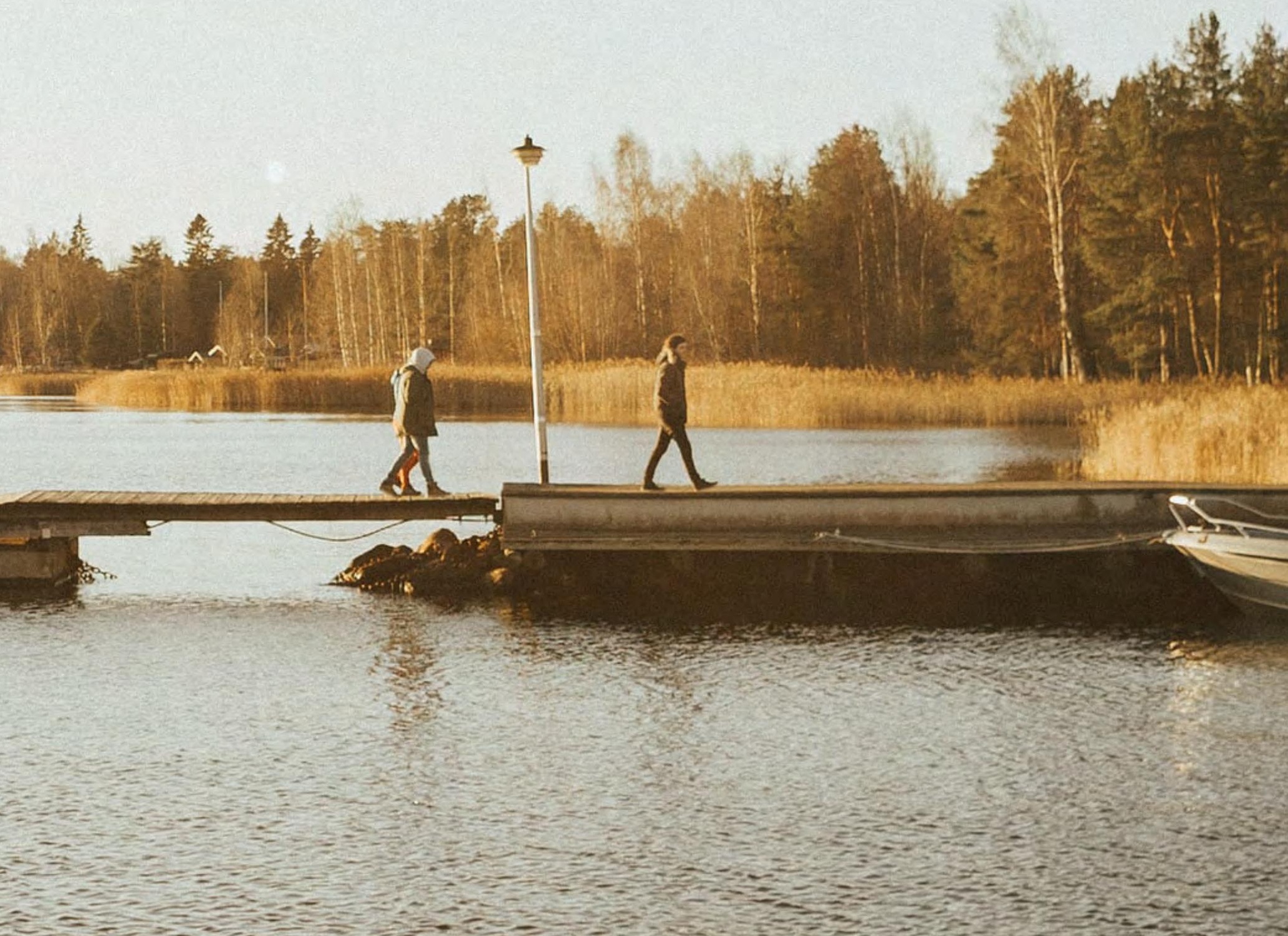





\section{Skills supply and governance in the Bothnian Arc cross-border region}

By Alberto Giacometti \& Alex Cuadrado

NORDREGIO REPORT 2020:10

Report prepared for the Nordic Thematic Group for Innovative and Resilient Regions 2017-2020, under the Nordic Council of Ministers. 
Nordregio Report 2020:10

ISBN 978-91-87295-27-0

ISSN $1403-2503$

DOI: http://doi.org/10.6027/R2020:10.1403-2503

(c) Nordregio 2020

Nordregio

P.O. Box 1658

SE-111 86 Stockholm, Sweden

nordregio@nordregio.org

www.nordregio.org

www.norden.org

Analyses and text: Alberto Giacometti \& Alex Cuadrado

Layout: Vaida Ražaitytè

Coverphoto: Ali Arif Soydaș / unsplash.com

\section{Nordregio}

is a leading Nordic and European research centre for regional development and planning, established by the Nordic Council of Ministers in 1997. We conduct solution-oriented and applied research, addressing current issues from both a research perspective and the viewpoint of policymakers and practitioners. Operating at the international, national, regional and local levels, Nordregio's research covers a wide geographic scope, with an emphasis on the Nordic and Baltic Sea Regions, Europe and the Arctic.

\section{The Nordic co-operation}

Nordic co-operation is one of the world's most extensive forms of regional collaboration, involving Denmark, Finland, Iceland, Norway, Sweden, and the Faroe Islands, Greenland, and Åland. Nordic co-operation has firm traditions in politics, the economy, and culture. It plays an important role in European and international collaboration, and aims at creating a strong Nordic community in a strong Europe. Nordic co-operation seeks to safeguard Nordic and regional interests and principles in the global community. Common Nordic values help the region solidify its position as one of the world's most innovative and competitive.

\section{The Nordic Council of Ministers}

is a forum of co-operation between the Nordic governments. The Nordic Council of Ministers implements Nordic co-operation. The prime ministers have the overall responsibility. Its activities are co-ordinated by the Nordic ministers for co-operation, the Nordic Committee for co-operation and portfolio ministers. Founded in 1971.

\section{The Nordic Council}

is a forum for co-operation between the Nordic parliaments and governments. The Council consists of 87 parliamentarians from the Nordic countries. The Nordic Council takes policy initiative $s$ and monitors Nordic co-operation. Founded in 1952. 


\section{Table of contents}

Foreword

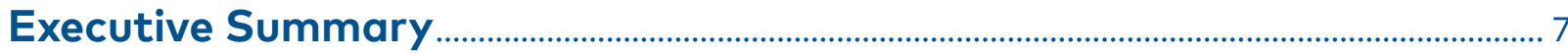

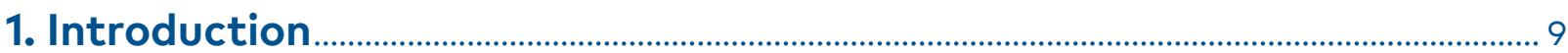

2. Skills Background Literature ........................................................................................ 10

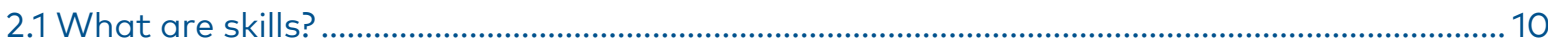

2.2 Why are skills a hot topic? ........................................................................................................ 11

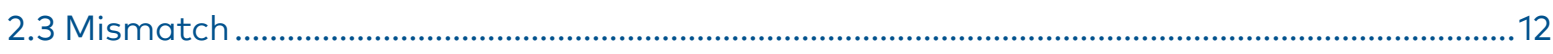

2.4 Skills development \& governance ..........................................................................................13

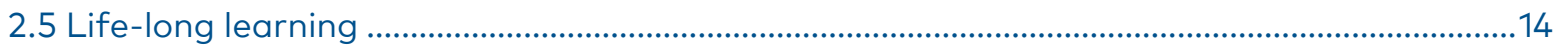

2.6 Labout mobility (cross-border \& beyond) ...................................................................................16

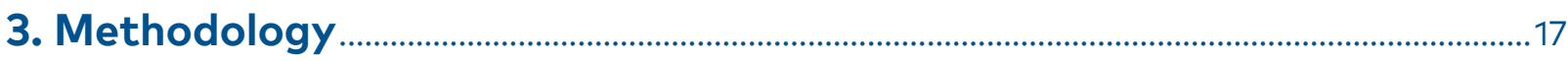

4. Case Study: Bothnian Arc Cross-Border Region ...................................................... 18

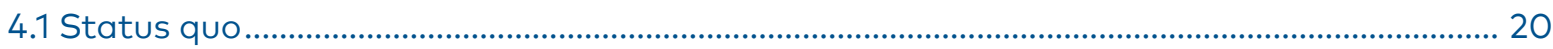

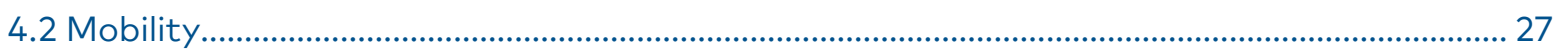

4.3 Skills development............................................................................................................... 32

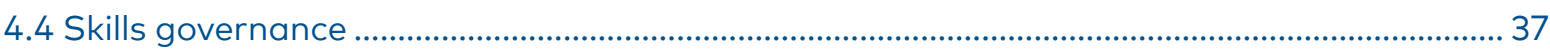

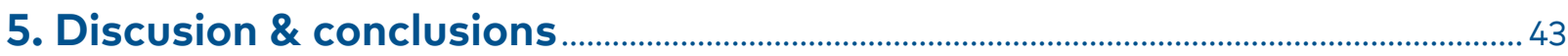

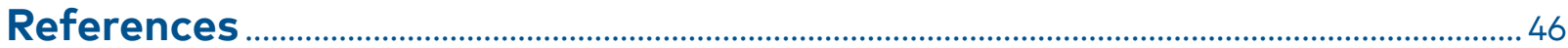

Interview List: Field Study carried in October 2019..........................................................................49 


\section{Foreward}

Nordregio, on behalf of the Nordic Council of Ministers Committee of the Civil Servants for Regional Affairs, is the secretariat for the Nordic thematic group for innovative and resilient regions 2017-2020. During this program, the Nordic thematic group has focused on expanding knowledge and identifying policy-relevant solutions to the challenges that Nordic regions face when it comes to resilience, smart specialisation, digitalisation, and skills. In 2019-2020, Nordregio conducted this study on skills supply, skills demand and mobility in the Bothnian Arc area with the aim of providing some answers to the specific skills related challenges in the area.

The Bothnian Arc cross-border area is a collaboration between municipalities across the state border between Finland and Sweden. It extends from the Swedish city of Skelleftea to Kokkola in Finland, along the coastal territories forming a horseshoe shape the surrounding Gulf of Bothnia. The labour and skills supply vary significantly within the Bothnian Arc area. The two middle-size cities of Oulu in Finland, and Luleå in Sweden are magnets for securing high levels of regional competence but generally the region suffers from major demographic challenges. The demand for skills varies significantly depending on the industrial composition of different municipalities.
The study aims to find answers to the following questions: 1) What is the current situation regarding the supply and demand of skills in the Bothnian Arc region? 2) What are the different forms of mismatch between the skills supply and demand? and, 3) What potential does cross-border mobility have in closing skills gaps in the region?

This report provides interesting insights into the developments concerning the who, when and how of skills development in a changing global landscape. With the rapid changes in technology and the labour markets structure, the role of lifelong learning is gaining significant importance. This study has also shed some lights on how distance work and new forms of work can help tackling the significant lack of labour in areas such as the Bothnian Arc with dire demographic developments. Finally, the study also identifies an untapped potential for complementing skills needs across the Finnish-Swedish municipalities through increased labour market integration.

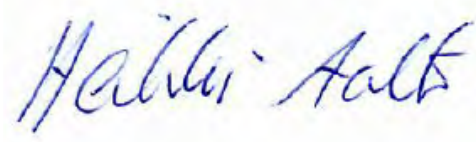

Heikki Aalto

CEO of Bothnian Arc Association 


\section{Executive Summary}

This study investigates the state of play of skills supply and demand in the Bothnian Arc cross-border region. Empirical evidence is gathered to shed light on some of the reasons behind the present and future challenges in meeting the demand for skills supply. The empirical evidence also pinpoints key types of mismatch between supply and demand and in which areas. The research investigates the different roles of education providers, employers, and a range of other regional actors in skills development and governance. Finally, specific attention was put on analysing the potential for cross-border labour mobility in closing some of the skills gaps in the labour markets across the Finnish-Swedish border.

This study builds on previous research carried out by Nordic Thematic Group on Innovative and Resilient Regions 2017 - 2020 established by the Nordic Council of Ministers. In particular, a study on Social and Economic Resilience in the Bothnian Arc Cross-Border Region (Giacometti et al. 2019), and a study on Skills Policies - Building Capacities for Innovative and Resilient Nordic Regions (Lundgren et al 2020).

Skills are essential for thriving societies, economies, and individuals. Every individual has a unique set of skills, acquired through formal education, experience, culture, and other informal forms of learning. There is no universal definition of skills as they have been theorised through different perspectives and disciplinary fields. Nevertheless, all perspectives converge on the instrumental value of skills. As opposed to plain knowledge, skills are generally referred to as serving a particular purpose.

Assuming skills' instrumental purpose, their value is directly related to the demand. However, the demand for skills changes as economies and societies evolve. The skills available in the labour market gain or lose value over time. Moreover, the skills pool in a community is in a constant state of flow. As people find their way through the professional life, they gain new experiences, change jobs, some migrate, and eventually retire. At the same time, young people grow up, acquire an education or some form of training, and enter the labour market with new skills and fresh perspectives. In this context, securing the availability of skills in a region is the main insurance for its future social and economic sustainability.

This study revealed a number of interesting results. The supply of skills depends on multiple factors, both from the supply and from the demand side. Labour supply in general is closely related to demographic trends. The Bothnian Arc region is exposed to three important demographic challenges: population decline, ageing, and urbanisation. While these trends affect major parts of the Nordic countries, they are particularly accentuated in the northernmost regions. Even cities like Oulu and Luleå have much more modest population growth compared to similar-size cities in southern Sweden and Finland. With a high proportion of the labourmarket force edging towards retirement, the regions are facing a monumental challenge in filling vacant positions. Moreover, high competition for labour at national and international levels puts the cross-border region in a disadvantageous position compared to its southern counterparts. This is partly due to its relative remoteness and climatic conditions. High competition for skilled workers is particularly pronounced in growing industries such as IT, but also in public services, such as healthcare and education.

Additionally, the rapid changes in societies and economies are challenging the need for certain skills, as well as the way we develop and govern these skills. Technological innovations generate demand for new types of skills while some existing skills become obsolete. Yet, changes in demand are not driven by technology alone but also by other trends that are socially and politically motivated, such as the 'green transition' demanding new methods and business models. This structural transformation of the labour market leads to skills' mismatch, which is the 'discrepancy between the qualifications and skills that individuals possess and those that are needed by the labour market' (Cedefop, 2015, p. 27). Skills mismatch is manifested in two forms: vertical mismatch occurs when qualification levels are either too high (overqualified) or too low (underqualified) in relation to 
the available jobs (Cedefop, 2019); and horizontal mismatch occurs when workers are employed in a different field from what they have specialised in (OECD, 2017, p. 16). Finland and Sweden do not score high in vertical mismatch in the European context (Pareliussen, 2016), however, the path dependency of the region with regards to the primary sector, namely natural resources extraction and process industries, has led to a high proportion of low educated workers. With increased automation and growing employment in services and technological industries some workers are at risk of longterm unemployment.

The present speed of the labour market transformation makes it difficult for the education systems and individuals to keep up with the skills needed. Continuous learning or life-long-learning has therefore become necessary for individuals to stay relevant and for the employers' competitive advantage. However, life-long learning challenges the way skills development has been traditionally conceived. It lifts the role of employers in providing learning opportunities and professional development guidance. More broadly, this puts to question how skills are governed and what the formal and informal roles of different actors are in generating and managing skills.

Generally, the education system remains the cornerstone in skills development by delivering foundational skills, but employers and multi-actor collaborations have become increasingly relevant in generating professional skills and life-long learning opportunities. There is also more pressure on individuals to be more active in updating their skillsets, while at the same time there are more opportunities for self-learning. Workplace learning appears to be the most direct way to influence an employee's professional development. In contrast to formal education, workplace training is rarely carried out in a systematic way. Workplace training is sporadic and often based on learningby-doing. It may also be based on ad-hoc initiatives typically connected to the specific employee's tasks. Arguably, workplace learning may often seem more utilitarian, in the sense that it is meant to serve the interest of the employer before the interests of the employee. However, there are ex- amples in the Bothnian Arc region of coordinated action between educators and employers in delivering education and training while also considering individual's own interests. These are mostly found in adult education schools and at Svefi, the Swedish-Finnish folk high school, which is a hybrid type of school that provides general education but also a range of tailored courses in many fields.

In the Bothnian Arc, different actors collaborate under different constellations to address the development and supply of skills from a general to a more practical level. For instance, local and regional authorities often collaborate with chambers of commerce, business organisations, universities, and employment services in predicting market trends and promoting the region, while adult education programmes are coordinated and developed alongside companies to tailor these to respond simultaneously to the labour market needs and individual needs. Finally, the employment agencies and employment consultants work more concretely with maximizing employment by linking jobseekers with employers. The links between employers and jobseekers appear to play a pivotal role in facilitating the match between the supply and the demand.

The Bothnian Arc, both on the Swedish and Finnish side, scores high on innovation capacity and entrepreneurship. This means that the regions are good at adapting to challenges and technological transformations. The highly collaborative environment also makes it easier to mobilise change. However, this will not ease demographic challenges. Cross-border labour mobility and labour market integration remains an important opportunity for overcoming some of the skills gaps. There is a need however, to overcome cultural differences and practical barriers that appear with crossborder integration. This has become particularly relevant in the midst of the Covid-19 pandemic, after uncoordinated responses between countries led to a hard border policy between the two countries. The unprecedented obstruction of borders has had severe consequences to many companies, workers, and to social integration. Rebuilding trust and re-establishing ties across borders will be essential for labour market integration. 


\section{Introduction}

Skills or competences are essential for thriving societies, economies, and individuals. Yet, the skills pool in communities and labour markets are in a constant state of flow as people grow older, others are just reaching working age, some migrate and other immigrate. Every individual carries with them a unique set of skills, which is a combination of knowledge and abilities acquired through formal education, experience, culture, and other informal forms of learning. Furthermore, some skills are timeless, or relevant at all times regardless of the point in history or degree of development in a region, whereas others lose or gain relevance. As societies, economies, and technologies change, certain skills become obsolete and others become needed, even types of skills that may have been unthinkable just some years back.

Previous studies carried out by the Nordic Thematic Group on Innovative and Resilient Regions 2017/2020 (set by the Nordic Council of Ministers) on resilience, smart specialisation and digitalisation have all thrown interesting findings about the importance of skills supply and adaptation in Nordic regions. Technological innovations, the green transition, demography, among other megatrends, are fundamentally challenging the ways economies and societies are organised today. Adapting to new conditions is a challenge for all countries, regions, and individuals. Possessing the right skills and being able to retain them is certainly one of the most important factors in winning or at least keeping up this highly competitive race.

Being relatively remote, the situation for the Bothnian Arc cross-border region is yet more challenging compared to core cities and regions in the
Nordic countries and Europe. Previous studies in the region, such as Social and Economic Resilience in the Bothnian Arc Cross-Border Region (Giacometti et al., 2019; Giacometti \& Teräs 2019a, 2019b), and Cross-Border Public Services (CPS): Case study Report - Bothnian Arc (Berlina 2018), have shed some light on the status of skills supply and demand, key challenges, and the opportunities of cross-border collaboration. Unfavourable demographic trends, such as emigration, urbanisation and a rapidly ageing population are the primary threat to skills supply and to the overall economic and social resilience of the region. At the same time, avant-garde technologies, universities, and businesses in combination with strong social ties and sense of belonging, represent a solid basis for the promising future development of the region.

This study aims to assess in greater detail the situation regarding skills supply and demand, and skills development in the Bothnian Arc cross-border region. In addition, mobility is given particular attention as a mechanism for filling some of the labour market gaps and complementing skills demand across the Finnish-Swedish border. Mobility is also seen as a threat as the possibility of 'brain drain' emerges. Emphasis is placed on identifying place-specific considerations to skills development in the region and possible actions for securing employment and economic competitiveness in the future. The conceptual framework of this study builds on a pan-Nordic study on the same topic titled: Skills Policies - Building Capacities for Innovative and Resilient Nordic Regions (Lundgren et al 2020). 


\section{Skills Background Literature}

\subsection{What are skills?}

From Nordregio's preliminary report: Skills Policies - Building Capacities for Innovative and Resilient Nordic Regions. Preliminary Report: Policy and Literature Review (Cuadrado et al., 2019 p.5):

"Skills are complex instruments whose definition changes depending on the theoretical perspective taken to approach the issue (Bryson, 2017) and the context within which skills are defined (Toner, 2011). Several disciplinary fields (e.g. economics, industrial relations, or political science among others) have studied and conceptualised skills, and there is no standard conceptual framework from which to understand skills in a comprehensive way (Smith \& Teicher, 2016). 'Each disciplinary perspective reveals and explores only part of the full picture of skill' (Bryson, 2017)."

Examples from practice define skills as:

- Skill are 'the ability to apply knowledge, use know-how to complete tasks and solve problems and carry out the tasks that comprise a particular job' (The European Centre for the Development of Vocational Training - CEDEFOP in Skills Panorama, 2019).

- Skills are 'individual characteristics that drive at least one dimension of individual wellbeing and socio-economic progress (productivity), that can be measured meaningfully (measurability), and that are malleable through environmental changes and investments (malleability)' (OECD, 2015, p. 34).

Cuadrado et al (2019 p.5) continue:

"Skills are instrumental because they serve both the individual and the collective agents in economic and social life (Bryson, 2017). At the individual level, developing skills is a way to secure or enhance one's position within the labour market and to grow human capabilities. At the collective level, a skilled workforce contributes to economies and workplace competitiveness and efficiency, as well as in generating new economic and employment opportunities."
According to the European Commission:

"Skills are a pathway to employability and prosperity. With the right skills, people are equipped for good-quality jobs and can fulfil their potential as confident, active citizens. In a fast- changing global economy, skills will to a great extent determine competitiveness and the capacity do drive innovation. They are a pull factor for investment and a catalyst in the virtuous circle of job creation and growth. They are key to social cohesion." (European Commission, 2016, p. 1)

Different actors are in charge of developing, recognizing and valuing skills. In simple terms, skills are developed by educational or training systems, recognized by state authorities, and valued by the labour market. Within these three arenas several actors including schools, companies, local and regional authorities or third sector actors, cooperate and compete to achieve their goals, and their actions often overlap. The boundaries are not clear-cut, skills development span from formal to non-formal arenas, not only at the school bench or the workplace, but through a multitude of forms of learning, such as self-learning and through professional and social networks.

From a governance perspective:

"skills policies are at the intersection between various sectors of the education system, including early childhood education and care (ECEC); schools; vocational education and training (VET); adult learning and higher education; labour market policies, especially those that aim to make use of existing skills such as active labour market and training policies; policies that support the adoption of high performance workplace practices; and certain immigration policies" (OECD, 2020, p.4).

In this sense, the skills system covers "all institutions and individuals, as well as policies, laws and regulations, concerned with the development and use of skills in the economy" (OECD 2020, p.4). 


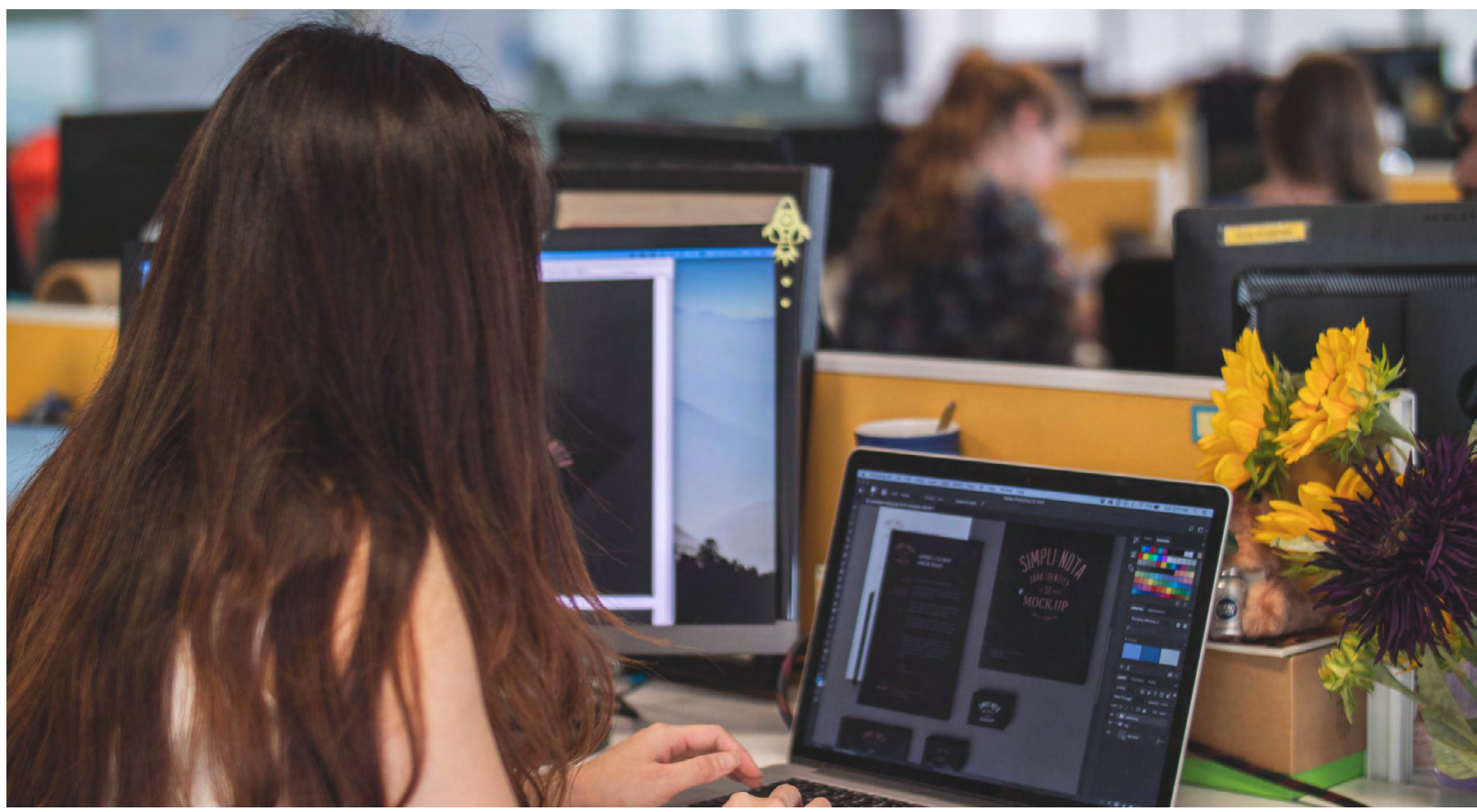

"Skills are a pathway to employability and prosperity". Photo: unsplash.com

However, a broader understanding of skills by the OECD (2019) distinguishes between cognitive and meta-cognitive skills, social and emotional skills, and practical and physical skills. While cognitive skills encompass knowledge on language, numbers and reasoning, meta-cognitive skills include the ability to recognize one's knowledge, skills, attitudes, and values (OECD, 2019). Social and emotional skills refer to the individual capacities for developing and exercising their civic responsibilities through their thoughts, feelings, and behaviours. Finally, physical, and practical skills relate to the ability to carry out functions demanding strength, flexibility, or other physical qualities.

More informally, different types of skills are distinguished between soft and hard skills. The former generally referring to the interpersonal communication, social and emotional skills. The latter refers to transferable skills, such as numeracy, literacy, technical or formally recognised skills needed to perform a work task or a professional judgment. (Cuadrado, 2019)

Finally, both hard and soft skills are generally referred to as instrumental, or serving a particular purpose as opposed to plain knowledge.

\subsection{Why are skills on the agenda?}

Global trends such as automation, the green transition and demography are leading to major transformation of the labour market. In a survey carried across nine countries (non-Nordic countries), "forty percent of employers said that lack of skills was the main reason for entry-level job vacancies, [and] sixty percent said that new graduates were not adequately prepared for the world of work" (Manyika, 2017). Additionally, one estimation reveals that up to "65\% of children entering primary school today will ultimately end up working in completely new job types that don't yet exist" (World Economic Forum, 2018). Therefore, there is a mismatch between the skills in demand and those available (supply) in the labour market. At the same time, the speed at which the employment landscape is changing makes predicting future needs challenging.

Technological innovation and other global megatrends transcend traditional structures and borders, still, their effects are geographically unbalanced. The local context, with their specific social and economic structures will be relevant in how the community adapts to these changes. Therefore, there is a need for generating understanding of how global megatrends will affect specific regions, and the sectors and citizens within it. 
Additionally, the demographic structure and current trends in the Bothnian Arc represent the biggest challenge in coping with labour supply. This includes labour in general, but also specific skills. Retaining existing workers and attracting new skilled workers, however, will not suffice to meet regional needs. Creative and unorthodox actions may be needed to satisfy the region's needs.

\subsection{Mismatch}

Skills mismatch is the 'discrepancy between the qualifications and skills that individuals possess and those that are needed by the labour market' (Cedefop, 2015, p. 27). This poses a problem for regional and national economies and for individuals as it reveals an underutilisation of the existing skills within the workforce. Causes for skills mismatch can be many but are currently being fuelled by the rapidly changing labour market through technological innovations and other global trends leading to a structural transformation of the labour market. There are also debates on whether education systems should be better adapting to the continuously changing labour market needs, or if firms and employers should be more proactive in providing training and generating attractive working conditions (Cedefop, 2015). Skills mismatch can be divided into vertical and horizontal mismatch. Vertical mismatch refers to the portion of the workforce that does not meet the skills demand because their qualification levels are either too high (overqualified) or too low (underqualified) in relation to the available jobs (Cedefop, 2019). And horizontal mismatch refers to a sectoral incompatibility or 'when workers are employed in a different field from what they have specialised in' (OECD, 2017, p. 16).

Vertical mismatch is directly related with skills development as the mismatch occurs when the workforce or a portion of it has too high or low levels of skills. According to the 2018 European Skills Index (Cedefop, 2019), Finland and Sweden have a high performance in skills development. In fact, Finland is the top performing Member State in skills development primarily because it provides possibilities to enhance skills beyond the compulsory level (Cedefop, 2019). Finland has the highest proportion of students in vocational education as well adults in lifelong learning, it continues to modernize school and vocational education, and presents Europe's highest attainment rates of tertiary education (Cedefop, 2019). Sweden also ranks high due to good performance in lifelong learning and adult education opportunities.

Despite the high performance in skills development, Finland and Sweden still have an important share of vertical mismatch. Pareliussen (2016) identifies a connection between demography and over- and underqualification in Finland. While the oldest (aged 55-64) workers tend to be underqualified due to the lack of schooling opportunities in previous decades, younger cohorts (aged 35-44 and 45-54) tend to be overqualified (Pareliussen, 2016). This situation is similar to other European countries. Between the years of 2007-2017 the percentage of underqualified labour has declined while in the percentage of overqualified labour has increased in almost all EU28 countries (Vandeplas \& Thum-Thysen, 2019). This suggests that as older workers retire and younger workers enter the labour market, the skills levels of the labour force raise. While Finland shows underqualification shares of around $20 \%$ and overqualification shares of $12 \%$, Sweden presents underqualification percentage of $30 \%$ and overqualification score of $8 \%$.

Furthermore, having high levels of skills does not necessarily mean that the region fulfils the skills demanded by different sectors. Imbalances in education and professional development in across sectors leads to horizontal mismatch.

Horizontal mismatch has negative consequences for the individual who is employed in a field other than that of his/her qualification. Such consequences are lower wages, lower levels of job satisfaction, and higher willingness to change jobs (Montt, 2017). Field mismatch is not solely an outcome of individual choices regarding education; the demand for skills in the labour market is one of the drivers of mismatch (Montt, 2017, p. 13). The literature on horizontal mismatch identifies three key determinants of horizontal mismatch: education; labour market; and job conditions (Somers et al., 2018).

First, a person's field of study has a direct impact on horizontal mismatch. For instance, liberal arts provide general skills while medical studies provide occupation-specific skills. Occupationspecific skills generally reduce horizontal mismatch (Somers et al., 2018). The timing of the education also plays a role. For example, the later in life individuals specialize, the lower the chances are to be employed in sectors different from their specialization (Somers et al., 2018) given that the 
more experience in the labour market the more clarity they have about their future preferences and opportunities. Second, the underlying context in the labour market is relevant. For instance, both high and very low unemployment rates increase the chances for horizontal mismatch. Third, the conditions of employment or size of a company also influence horizontal mismatch. Temporary contracts increase the probabilities for horizontal mismatch because the employee is not able to acquire sufficient work experience and employers are not willing to invest in training (Somers et al., 2018). Also, workers in larger companies are likely to be less horizontally mismatched due to the wider range of opportunities they can find within their company (Somers et al., 2018).

According to Montt (2017), both Finland and Sweden show relatively low scores of horizontal mismatch. In a comparison encompassing 23 OECD countries, Finland shows a $16.1 \%$ of field mismatch among its workforce and comes second only behind Germany with $15.7 \%$. Sweden shows a slightly higher percentage (21.8\%) but still below average (25.4\%) (Montt, 2017, p. 11). Despite of the good performance of Sweden and Finland within the international context, there are large regional differences in both countries.

\subsection{Skills development \& governance}

Skills development in different countries and regions depends to a large extent on their institutional and regulatory frameworks. However, institutional frameworks exist in a broader arena of skills development and governance, which can be understood as 'skills-ecosystems'. Skills eco-

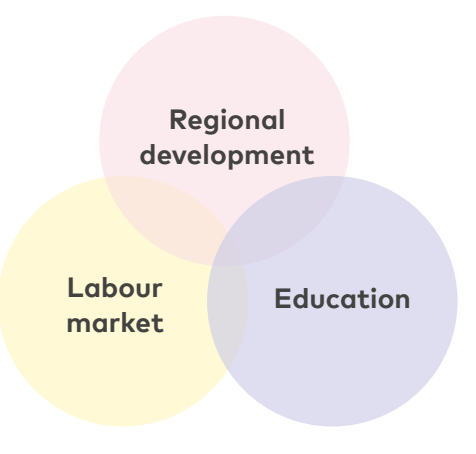

Figure 1. Overlapping areas for skills development. Source: Lundgren, A. et al (2020). systems are 'regional or sectoral social formations in which human capability is developed and deployed for productive purposes' (Finegold, 1999 in Buchanan et al., 2017). Figure 1 illustrates the location of skills at the intersection of regional and sectoral formations referred by Finegold. Public authorities responsible for regional development, education institutions, and regional labour market actors work within these three overlapping areas and form skills ecosystems. Based on cooperative efforts to achieve their goals, the actors are, nonetheless. constrained or enabled by the institutional framework in which they are embedded.

Skills development cannot be seen from the regional perspective alone. Governmental and nongovernmental actors at the municipal, regional, national, or supranational levels, are also involved in the development and deployment of human capabilities for productive purposes. It is in this context that literature has theorised the existence of other institutional frameworks such as worlds of skills formation (Busemeyer, 2014) or varieties of institutionalism (Oliver et al., 2019). The world of skills perspective identifies roughly three regimes based on several indicators such as education spending, employers' involvement in training, and the education level of the population. These regimes distinguish the major differences in the relationship between education and the welfare state in different countries (Busemeyer, 2014).

The liberal regime, encompassing mostly Anglo-Saxon countries like the UK, the US, Canada, and Australia, is characterized by medium levels of public expenditure in education, above-average levels of private education, and low employer involvement in training (Busemeyer, 2014). The collective regimes, of which Germany, Switzerland, Austria (and to some extent Denmark and the Netherlands) are representative examples, are characterised by below-average levels of public spending in education, above-average levels of private spending in education, and above-average educational levels of the population. Finally, the statist regime, mainly made up of the Scandinavian or Nordic countries, is opposite of the liberal regime in that public expenditure in education is above-average, private expenditure in education is below-average, and, although employer involvement in training is low, vocational education enjoys higher status in education systems and the educational level of the population is above-average (Busemeyer, 2014). 
Despite the significant role played by the public sector in formal education in statist regimes, such as Sweden and Finland, the public sector role in skills development and governance outside formal education is often unclear and overlapping.

Formal education is key to ensuring basic skills in society at large. The different stages and areas of education are cornerstone arenas for skills development. Primary, secondary, and tertiary education prepare individuals for different aspects of working life but also other aspects of life in general. These range from basic skills such as literacy and numeracy, to hard skills, such as science and IT skills, to soft skills, such as analytical thinking, communication, teamwork, or problem solving. However, some of these skills are not developed at one stage of the educational trajectory alone, but through all stages and areas of education and beyond. These are known as transversal skills, as they can be transferred from setting to setting, and across workplaces.

While primary and secondary education focus on building basic skills needed by everyone regardless of their future careers, tertiary education focuses on developing specialised professionals. Tertiary education is therefore more sensitive to changes in the labour market. Additionally, vocational education is an alternative to tertiary education in developing skills for non-academic professions.

Aside from building the ground for equal opportunities, skills are useful for regional development. Skills are essential for economic performance and boosting competitiveness in general. These instrumental purposes of skills development are of the interest of companies that aim at generating economic gains, and regional authorities, who are interested in generating job opportunities, develop innovative industries, and ensure an efficient public administration. In addition, each particular region has its own specific potential from which to build wealth. Skills need also to correspond to these regional needs.

Companies and employers play a pivotal role in generating practical skills needed to perform the specific workings tasks. Work-place learning can have varying degrees of systematisation. Often this occurs in ad-hoc manners, but there are also specific industries or employers that require rigorous training processes, particularly in highly scientific or technical fields. Furthermore, looking from the lens of Regional Innovation Systems (RIS) theory, knowledge and skills in a region are created and circulated across social and professional networks. This occurs through different forms of multi-actor collaborations within R\&D, projects of different kinds, in clusters or simply through social relations.

There are varying levels of coordination between public authorities, educational institutions, and industries, resulting the definitions and vision of what types of skills are needed in their territories. Regional development strategies, including e.g. Smart Specialisation Strategies, generally address the market needs and defines actions to satisfy them. For instance, strategies in Norrbotten, Northern Ostrobothnia and Lapland address the need of generating digital skills amongst the population. A divorce between these actors in determining regional skills needs can generate serious imbalances in the market, such as a mismatch between supply and demand of skills.

\subsection{Life-long learning}

"One essential aspect of professional work is continuously developing competence" (Parding \& Berg-Jansson, 2017, p. 109).

In the policy arena this is commonly referred to as life-long learning. Life-long learning or 'continuous professional learning', does not entail a specific practice, but it can be referred to as different formal and informal means of acquiring knowledge and skills throughout the professional life. Until recently, literature and policy on professional learning had centred on formal learning organised outside the workplace and considered professionals passive learners. In this light, Parding and Berg-Jansson (2017) note that the focus of professional learning is often placed on delivering content rather than on integrated learning processes, which would entail that the workers themselves influence what and how to learn. The authors suggest that this focus ignores the dynamics of how learning occurs. 


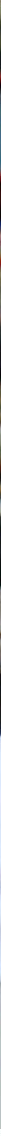

"Regardless of the way in which lifelong learning occurs, what is important is to keep up with skills development throughout the professional life, both from an individual and a collective level". Photo: unsplash.com

According to Parding and Berg-Jansson (2017), there is substantial literature that identify colleagues as one of people's main source of know-how. In their words: "teachers identify their subject colleagues as essential for everyday learning, emphasizing the importance of their physical proximity to subject colleagues". This would suggest that learning from peers can be more effective than more formal forms of education. Therefore, Parding and Berg-Jansson (2017), emphasise, that for learning activities to be useful in professional life, they must be embedded within the working task, and they also need to involve collaboration amongst peers. This can also be related to 'organisational learning' which entails knowledge creation and retention at a collective organisational level. Yet, learning can be "encouraged or obstructed by the design of the organization" (Ellström and Kock, 2008 in Parding and BergJansson, 2017). This would depend on a variety of conditions internally to an organisation, from how tasks are being assigned, to leadership, and the overall working environment.
Regardless of the way in which lifelong learning occurs, what is important is to keep up with skills development throughout the professional life, both from an individual and a collective level. This may imply that companies, and employers generally, take a bigger role in skills development for example by establishing more bridges between employers and education institutions. It may also imply a reform of the educational institutions to provide education opportunities throughout the professional life. Additionally, there is a discursive shift away from considering the professional a passive learner, to an active learner deciding what and how to learn, and altogether how to steer their own long-term professional path. This means that the responsibility for skills acquisition is more heavily placed on the individual, while the responsibility for delivering skills is increasingly diversifying. 


\subsection{Labour mobility (Cross border \& beyond)}

Apart from skills creation a major concern for many regions and companies is attracting new skills and skills retention, as in attracting skilled people to settle in the region and incentivise people already living there to stay. It is in this context that mobility plays a crucial role in satisfying or depriving regions and employers from the labour and skills they need.

Labour markets are rarely limited to administrative units, either local, regional, or national jurisdictions. However, administrative units generally advocate its own interests and compete for skills with other administrative units. Strategies and actions for skills supply and development are therefore bound to jurisdictional units. Moreover, statistics are mostly collected and communicated within these jurisdictions. This discrepancy between data and policy, and the reality of how labour markets function call for specific attention on e.g. mobility or other forms of responding to skills demands that do not specifically require new people moving to the region. Mobility threatens skills supply through brain-drain, but it is also an opportunity for gaining skills through cross-border networks and complementary labour markets.

Physical relocation of labourers from one region to the other, however, is not the only way of complementing labour markets across-borders. Companies can offer services at either side of the border without requiring their staff to relocate. Additionally, people and companies can provide services and allow distance working. Therefore, skills supply is not merely an issue of local labour markets, as it can be complemented by services and a labour force from different regions. There is, however, a certain level of discrepancy in how public sector designs its strategies compared to how private sector and businesses satisfy their skills' needs.

Migration patterns according to education level. Highly educated people have generally a higher access to information and are therefore more able to find job opportunities elsewhere, or in other words be more mobile (Böckerman et al., 2018). Additionally, some literature suggests that the "agony of departure from family and friends are likely to decrease with education" (Haapanen \& Böckerman, 2016, 5). The financial risk and uncertainty of migrating is often less pronounced with educated people, partly because they often only move once they have a job offer. However, there are many other factors influencing people's choice to move or not to do so. These are often related to culture, or individual values / personality traits, e.g. cultural values, social ties, attachment to a place, perceptions of migration, willingness to move and upbringing. These observations need to be tested across countries and regions. Kotavaara (2018) shows that university graduates in Finland tend to be highly mobile within the first year after graduation, while they tend to settle after that. Some explanations for this show that the low degree of mobility after the first year are of a personal character rather than professional one. University graduates are rather flexible in the beginning, but many get attached once they find their first job, a partner or buy an apartment (interviews).

In Kotavaara's words, "within the mediumsized city regions and the declining city regions [in Finland] the share of university graduates who move to the capital city region is even larger than the share of stayers." (Kotavaara 2018, p.102). Thus, graduates are immobile in capital and large city-regions, which agglomerate $75 \%$ of graduates, while they are highly mobile in less urban regions. Haapanen and Tervo (2012) also noticed a "higher out-migration, or brain drain, in the more peripheral university regions than in the growth centres, especially in the capital region" (p. 98).

However, a researcher at Oulu university criticises how mobility among the highly educated is counted in the statistics, arguing that many highly educated people migrated before attaining an education and often precisely for this purpose. They made the move to a place, typically and urban area, that offers more education and labour opportunities than for instance rural areas and small towns. Therefore, those who moved to urban areas do not necessarily need to move again to find a job matching their profession. 


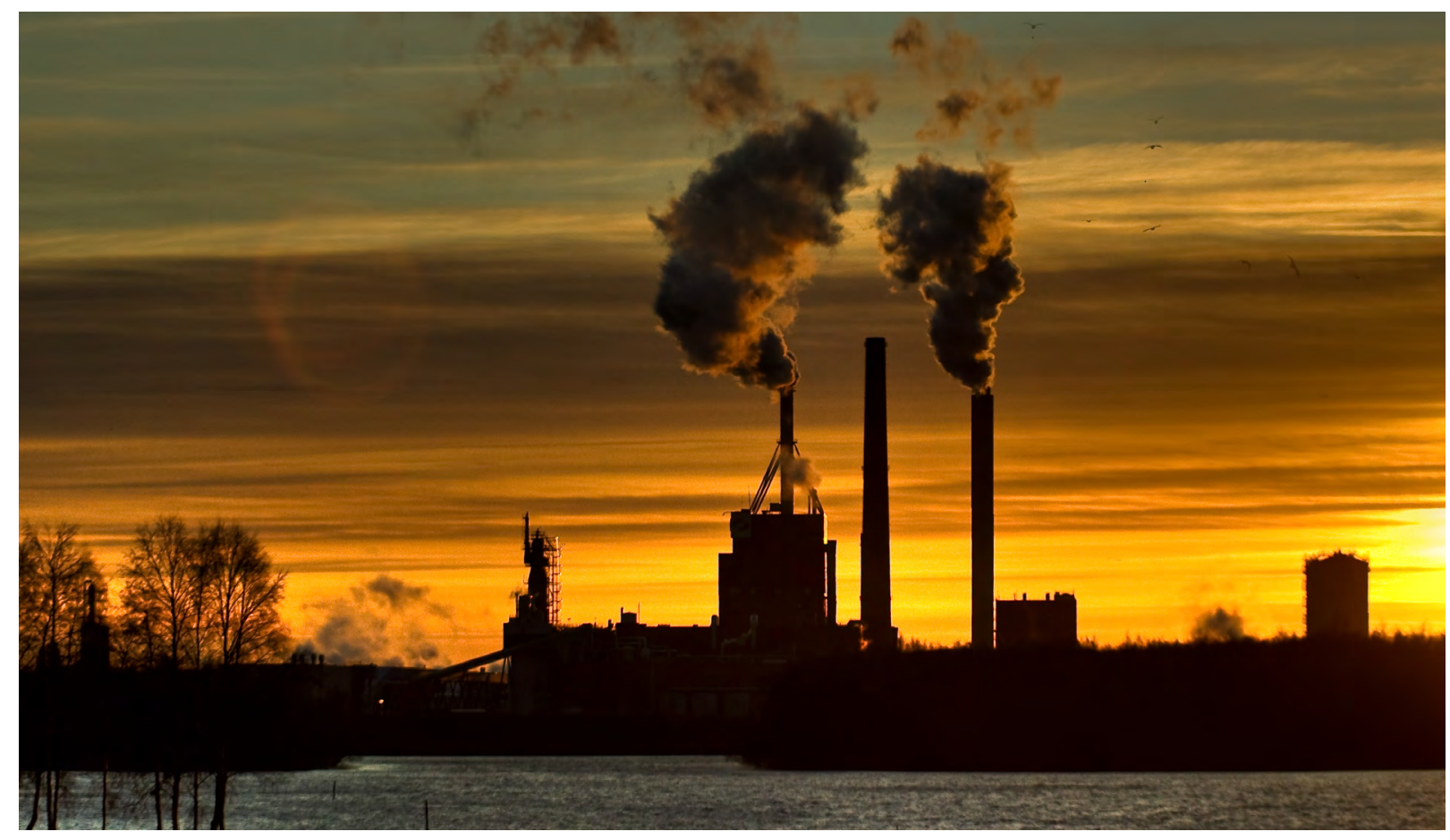

"Finland tend to be highly mobile within the first year after graduation, while they tend to settle after that". Photo: Juho Tastula / freeimages.com

\section{Methodology}

This study combines desk-research with fieldwork to gather theoretical and empirical evidence. The theoretical discussion was based on a preceding study: Skills Policies - Building Capacities for Innovative and Resilient Nordic Regions. Preliminary Report: Policy and Literature Review (Cuadrado et al., 2019); and final report with the same name (Lundgren et al, 2020). This work provided the ground for the theoretical and policy background an empirical evidence in other Nordic regions. This study builds on work by Cuadrado et al (2019) and Lundgren et al (2020) and adds perspectives relevant to cross-border dynamics of skills development and skills mobility. Existing research on skills mobility was analysed for this purpose.

Interviews were conducted in October 2019 in several locations across the Bothnian Arc region with key stakeholders from regional and local administrations, local employment service, business organisations and chambers of commerce, crossborder organisations, academics, the Svefi binational folk school and employment consultants.
The empirical material was also complemented with the evidence collected for a preceding study on the same region titled: "Social and Economic Resilience in the Bothnian Arc Cross-Border Region" by Giacometti et al (2019).

For the analysis, a qualitative approach was utilised to study what the major challenges are regarding skills supply and demand in the Bothnian arc cross-border region. Furthermore, the analysis takes a deep dive into the roles of responsibilities that different actors play in skills development and governance, and what are the potentials of labour mobility in filling the labour market gaps. The analysis does not provide a full picture of all the policies and actors relevant in skills development and governance but focuses on what has been highlighted by the local informants. The analysis is not intended for making judgments on what practices should or should not be done but aims to shed some light on the complexity of skills governance in cross-border areas. 


\section{Case Study: Bothnian Arc Cross-Border Region}

The Bothnian Arc is a border area across the state border between Finland and Sweden. It extends from the Swedish city of Skelleftea to Kokkola in Finland, along the coastal territories forming a horseshoe shape the surrounding Gulf of Bothnia (see Map 1). The labour and skills supply vary significantly across the Bothnian Arc area. The two middle-size cities of Oulu in Finland, and Luleå in Sweden are a magnet for the regions' competences concentrating a number of global IT firms and manufacturing industries as well as universities. Yet, the region is generally challenged by the insufficient labour supply. The demand for skills varies significantly depending on the industrial composition of different municipalities.

When exploring the situation of supply and demand of skills in the Bothnian Arc region, it is impossible to neglect the underlying demographic trends. Setting aside the availability of specific skills, most of the interviewees and the figures alert that all sectors are being deprived of labour.
According to Norrbotten's chamber of commerce: "the lack of labour and competences is generalised in all companies, in every field; and companies are well aware of this". Likewise, on the Finnish side, Northern Ostrobothnia Business association states that "the problem of finding employees is present in all types of businesses". Moreover, demographic trends show a dire scenario for labour supply over the coming years. The informant from Luleå's business organisation (Näringsliv) speaks of "dark clouds coming over", while a researcher at Luleå Technical University (LTU) emphasises that this is not a future issue, "but the problem is here and now!".

Aside from the underlying issue of a scarce labour force, there are many nuances to the supply and demand of skills; the match or mismatch between the skills available in the labour market and those in demand depend on geography, sector, education, among other factors.

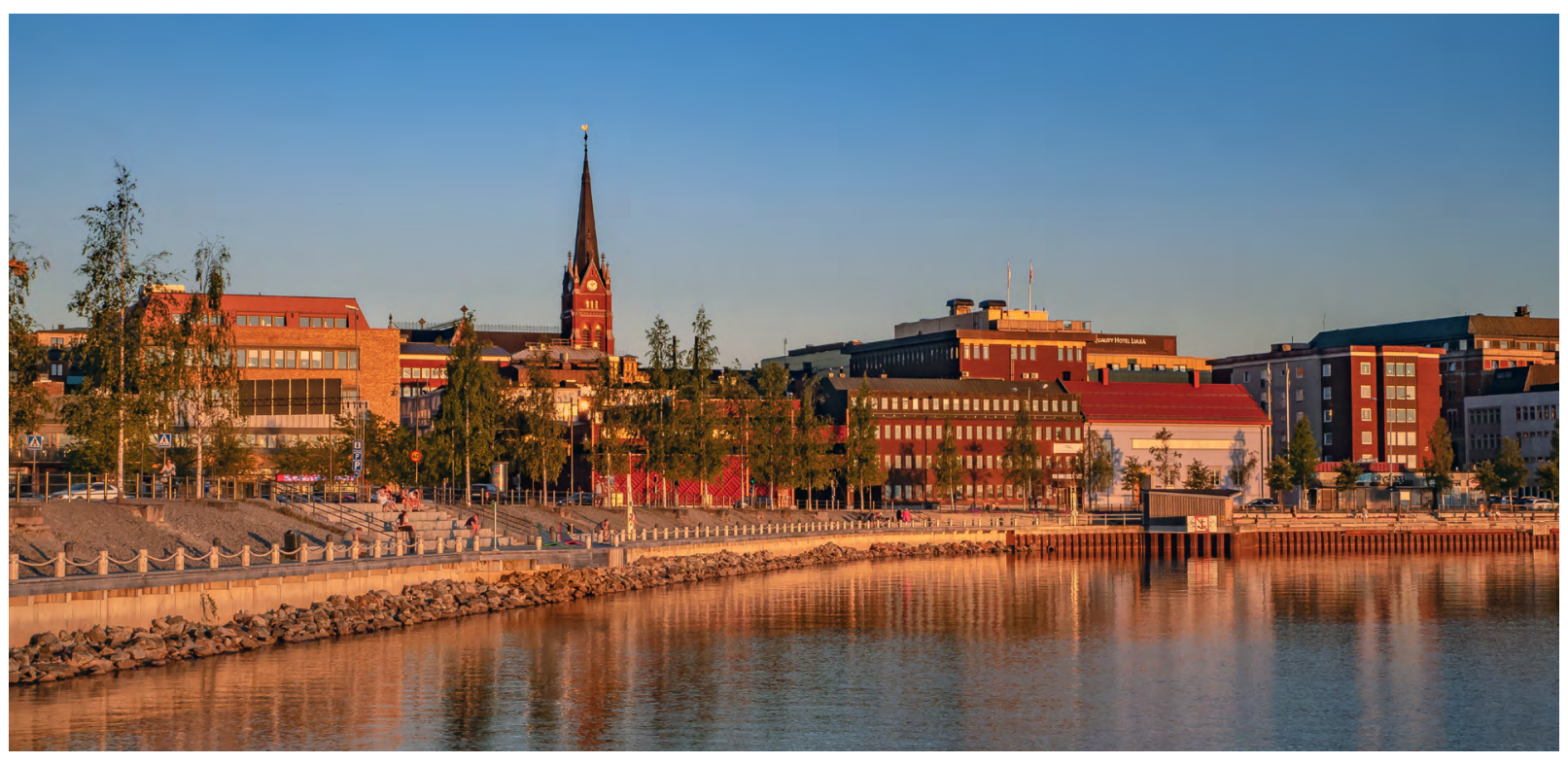

Lulea is one of the magnets for the regions' competences concentrating a number of global IT firms and manufacturing industries as well as universities. Photo: pixabay.com 


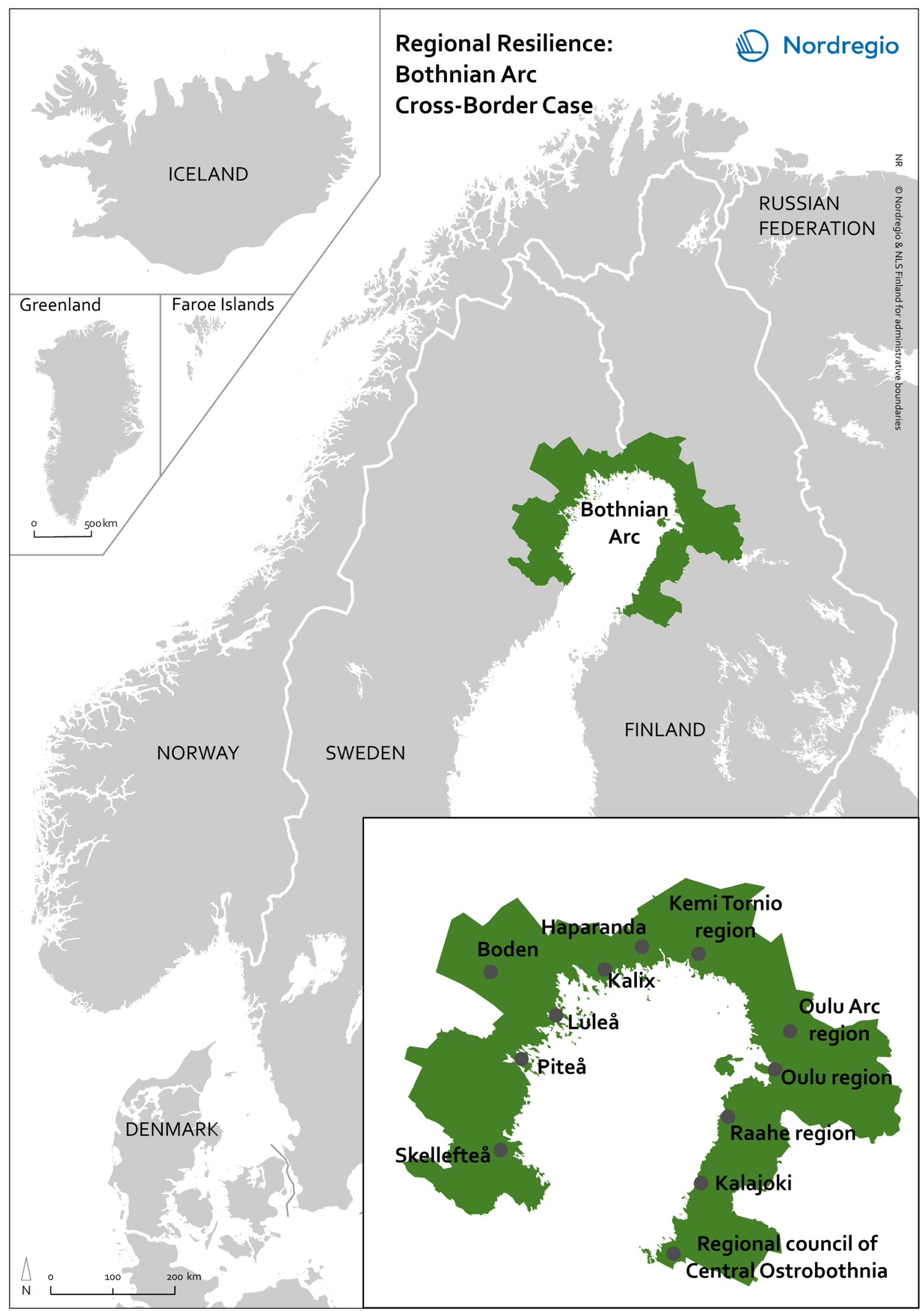

Map 1. Bothnian Arc cross-border region. *Note: Map based on 2019 members list. Today 'Raahe region' should read 'Raahe'. Source: Eeva Turunen in Giacometti et al (2019) 


\subsection{Status quo}

\subsubsection{Demography \& Labour Market}

Demographic decline is a general trend in Norrbotten, Lapland and Northern Ostrobothnia regions. Projections show that by 2040, Lapland will have lost $8.4 \%$ and North Ostrobothnia $3 \%$ of their 2020 population (Statistics Finland, 2019a). The trend in Norrbotten will have a similar impact as the region will lose $8.3 \%$ of its population by 2040 (Statistics Sweden, 2020). Although the population decline in these regions will not be the highest in Finland and Sweden, they are more severe than the national averages. Finland will experience a $0.2 \%$ population decline by 2040, Sweden will experience a population increase of $10.7 \%$. Population change differs significantly across different municipalities and areas, particularly to the benefit of urban and coastal areas. While the population decreases in most places in the Northern-most regions of Sweden and Finland, urban centres such as Luleå, Piteå, Oulu, Kempele and Rovaniemi have experienced a modest increase. In the future, the urbanisation trend is likely to persist to some extent, according to projections for the period of 2017-2040 (Sanchez Gassen \& Heleniak, 2019). However, these projections also show a change in the trend, with only Luleå being expected to experience a modest population increase in Norrbotten, while Rovaniemi and surrounding municipalities are expected to increase in Lapland, as well as Oulu and the surrounding municipalities in Northern Ostrobothnia (See figure 2).

The urbanisation trend is driving many people out of the region, and especially from remote areas. Even growing cities in the Bothnian Arc are experiencing a low growth rate compared to comparable sized cities in the south of Sweden and Finland. In Oulu and Kempele, roughly half of the population increase is attributed to natural growth and the other half through immigration. In more 'attractive' cities, such as Tampere and Helsinki, a significant majority of the increase comes from immigration. However, statistics can lead to misguided conclusions, an official from Oulu city states, "because most of those coming in are students who then move away". A significant part of that increase is temporary as the region is not being able to integrate all students into the labourmarket after graduation. While the biggest internal migration can be found in the age group of 20-to-29, there is negative net migration in the age group between 30-39 (Statistics Finland, 2019).

"Retirement trends will intensify labour scarcity in traditional jobs the most, such as nurses and teachers, administrators, technicians, engineers, truck drivers and construction/repairmen". Photo: Vaida Ražaitytė

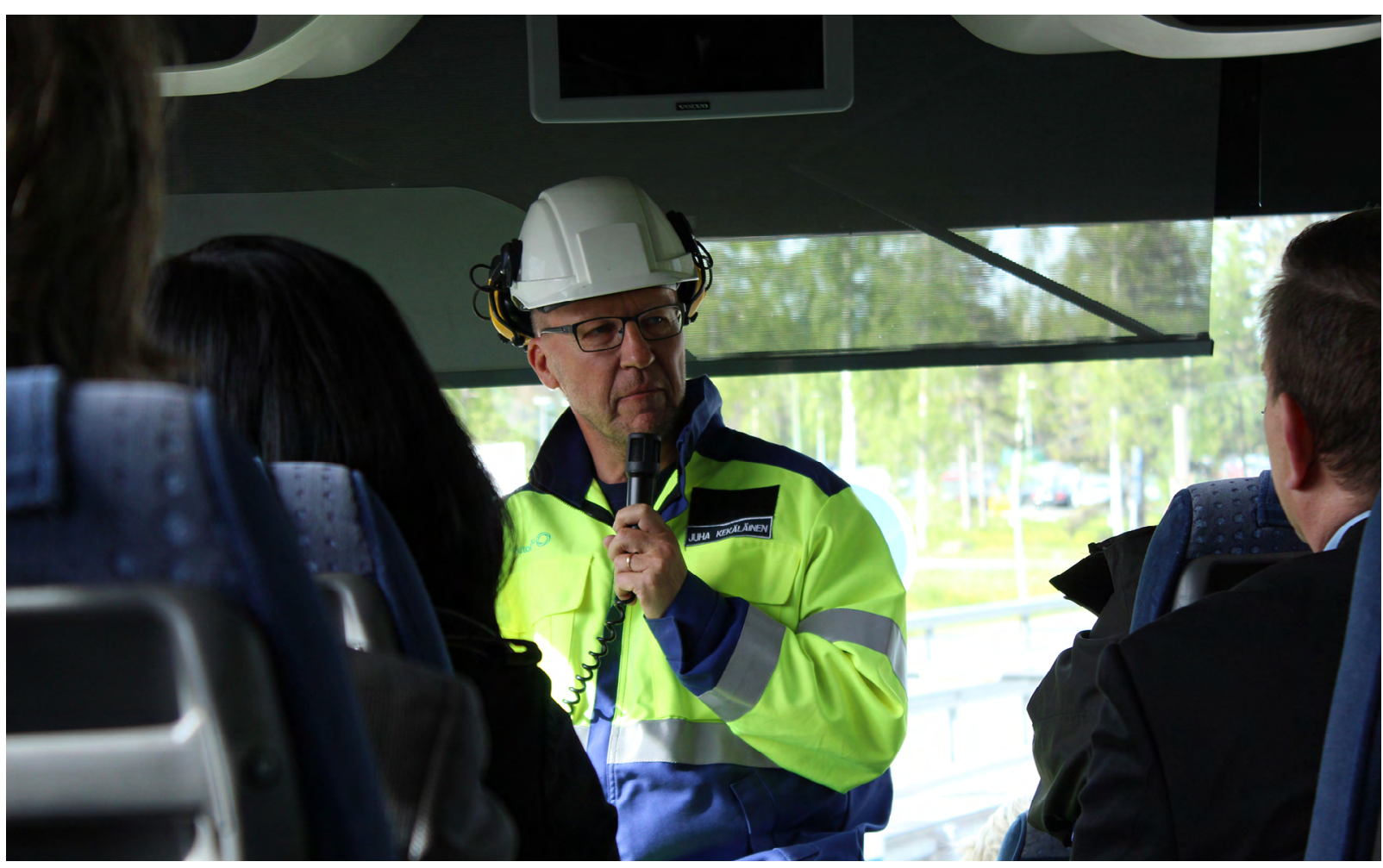




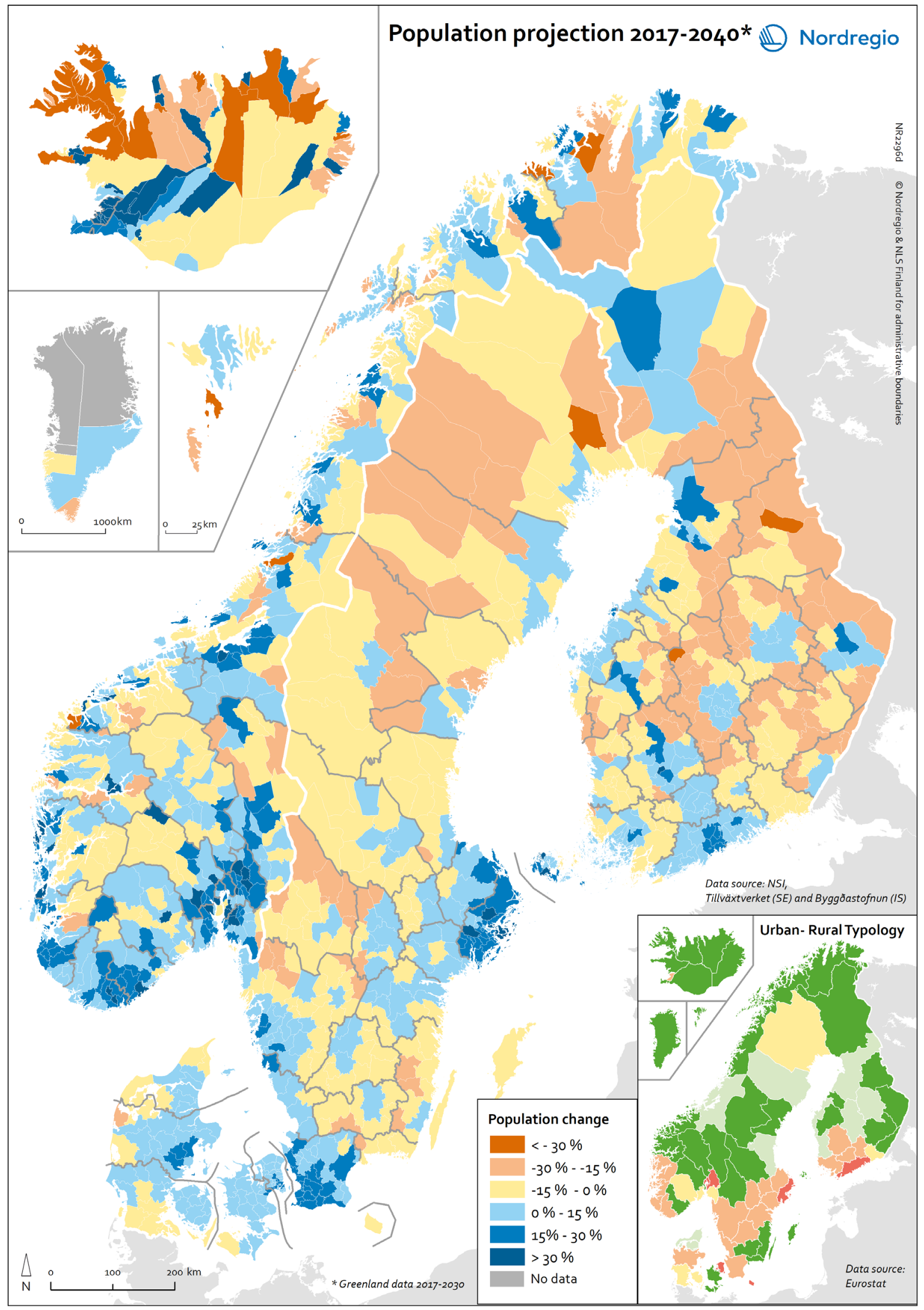

Map 2: Expected population change in Nordic municipalities: 2017 and 2040.

Source: Sánchez Gassen \& Heleniak (2019), Nordregio 
On the Swedish side, the brain drain is very pronounced among the female population, generating a gender imbalance in the demographic profile of the Norrbotten region. Likewise, the internal net migration for 30-39-year olds in Norrbotten is negative everywhere except Piteå. In contrast, large parts of Finnish Lapland experience positive internal net migration for the same age group, which is probably related to the growing tourism industry.

According to the inclusion strategist at Lulea municipality " $42 \%$ of the people working in the welfare sector in Norrbotten will be retiring by 2030, and up to $50 \%$ of teachers (...) this is a gigantic challenge" the interviewee states. Other sectors are not far behind, manufacturing and mining expect a $39 \%$ retirement rate by the same year (Ejdemo \& Parding, 2018). Retirement is not only a problem with employees, but with employers as well. According to an interviewee from Northern Ostrobothnia county, a large number of "company owners are retiring in the near future and there is no one who wants to take over". At the same time "most jobs are found in small companies; many are family companies", states the same informant. The number of retirees will be hardly replaceable. Retirement trends will intensify labour scarcity in traditional jobs the most, such as nurses and teachers, administrators, technicians, engineers, truck drivers and construction/repairmen (Ejdemo \& Parding, 2018). However, labour scarcity is generalised in all sectors, including IT, tourism, and other growing industries.

In a recent study Ejdemo \& Parding (2018) estimate that some 51000 recruitments are needed between 2013-2030 in Norrbotten. Even if the expected economic growth for that period was cut by a half, the researchers estimate recruitment needs to reach 46700 . This means that regardless of the economic performance of the region, the labour demand will be high and well above the capacity of the region to supply labour.

A moderate increase in retired people going back to work has been perceived amongst interviewees. This emerging trend was said to respond to the need of labour and experience, but also because people are generally living a longer and healthier life. Even if only for a few hours or even seasonally, this is something that needs to be considered seriously several interviewees believe. As an anecdote, an informant recalls:
"Yesterday, my mother took my daughter to school, and she didn't come back home - she was a teacher too, so she was asked to stay as they were lacking a substitute - so she did".

Skills and labour needs, however, vary geographically throughout the Bothnian Arc region. Rural and remote areas suffer the most from emigration, as young people and skilled professionals move out to bigger towns, cities, and to South Sweden and Finland. Aside from the generalised need for labour, the skills demand also varies across the region. The need for welfare workers can be generalised to any part of the region, as well as to professions such as builders and carpenters. Other needs are to an extent connected to the local industries, such as IT, engineers, and technicians.

Close to the border area, an informant stresses that "the lack of labour is the reason why our companies are not developing nor growing". This suggests that there is a potential for companies to develop if there was a higher labour supply. she is concerned that "people do not want to live here, despite the living costs are much lower than Helsinki and Stockholm".

Despite the large need for labour in the Bothnian Arc, unemployment rates are above the national average (6.7\%) in Lapland and North Ostrobothnia with $8.3 \%$ and $8 \%$, respectively in 2019 (Statistics Finland, 2019b). Nonetheless, a positive trend is identified when comparing the situation in 2019 with the previous year. Predictions for 2019 showed that an increased labour demand would result in a drop in the unemployment rate of $12 \%$ in Lapland and $10 \%$ in North Ostrobothnia (European Commission, 2019b). The situation is reversed on the Swedish side, in Norrbotten county where unemployment $(5.1 \%)$ has continuously declined since 2017 (Statistics Sweden, 2020) and is below the national average (6.7\%) in 2019 (European Commission, 2019c). Compared to the regional averages, employment in the Bothnian Arc area lays some percentage points below Norrbotten, but well above Lapland and Northern Ostrobothnia (see Figure 2). Note, that these numbers were collected before the crisis triggered by the Covid-19 pandemic, which is expected to have had a significant impact on the figures. 


\section{Employment rate 2005-2018}

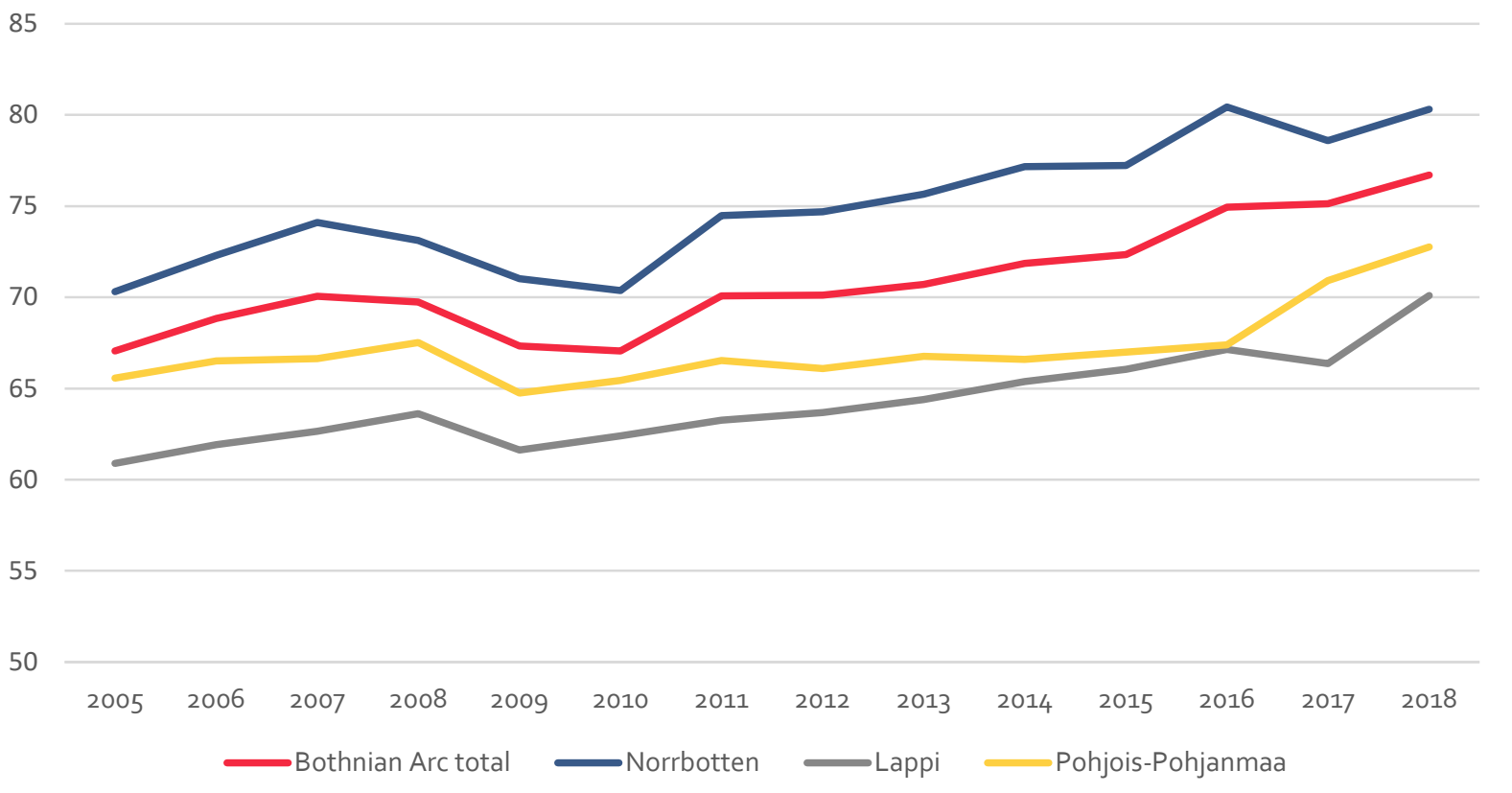

Figure 2. Employment rate in Bothnian Arc compared to Norrbotten, Lapland and Northern Ostrobothnia (PohoisPohjanmaa) regions. Source: Gustaf Norlén, Nordregio based on Finland's and Sweden's National Statistics.

The labour market structure and labour demand are not evenly distributed throughout the territory nor across industries. In Norrbotten, the public sector is the biggest employer, both at the regional and local levels. Municipal authorities are the single biggest local employer in most cases (European Commission, 2019c). Large private employers in Norrbotten are mining and process industries, including $L K A B$, Boliden Mineral $A B$, $S S A B$, Ferruform $A B$, Smurfit Kappa Kraftliner Piteå $A B$ and Billerud Korsnäs $A B$ (ibid.). However, the service industry is the biggest employer in the Luleå area with a strong IT sector, public administration, and construction. Tourism and hospitality sectors are on the rise, also outside the urban centres. Activities surrounding car testing have a role to play in increased hospitality and catering services, as well as for enhancing seasonal employment (ibid.).
In Northern Ostrobothnia, the public sector is also a major employer, particularly in healthcare and education. However, there are several large private employers within the IT sector and electronics industries, including Nokia, Elektrobit, Polar, in the metal industry with SSAB, and others in mechanical engineering, construction, commerce and services (European Commission, 2019b).

The labour market structure in Lapland is quite different than the other two regions. The private sector accounts for $64 \%$ of the jobs, where $80 \%$ of companies are micro-businesses with fewer than 5 employees (European Commission, 2019a). This business-driven region is rather versatile with a diverse range of sectors from tourism, small scale industry and mining, and a promising bioeconomy sector (ibid.). 


\subsubsection{Mismatch of skills supply and demand}

Besides demographic trends, there are other reasons why employers struggle to find the right skills, and for jobseekers to find the right employers. On the Finnish side, there is relatively high unemployment in spite of high labour demand. In other words, there is a mismatch between the supply and demand of labour and skills. Oulu employment agency confirms this finding stating that "the most important explanation for high unemployment is the miss-match between supply and demand". However, Business Oulu notes that "the scarcity for certain skills is quite similar across the Nordic countries; thus, it is not merely a local problem - for instance there is a general need for IT skills everywhere". This means that for certain industries the deficit in supply is not related to geography alone but relates to general gap in the market. Similarly, the Norrbotten chamber of commers corroborates this argument and is of the opinion that market changes are not being followed by sufficiently quick changes in the education system and regional development strategies. The number of graduates for certain professions is often too low for the actual demand. The number of jobs and the need for new skills in the IT sector is growing at such a speed that it exceeds the capacity of the education system to prepare new professionals.

There are different forms of mismatch between the supply and demand of skills, however. Factors related to education, validation, re-skilling, as well as institutional or structural issues play a relevant role in determining skills supply and demand in the Bothnian Arc.

Vertical mismatch (over- and underqualification) According to Business Oulu "many people do not have the right level of skills. Many are undereducated, but also many are overeducated, which have to go down to do jobs that require a lower degree of skill". Many young people are attracted to the labour market from an early age due to the high salaries offered by process industries, such as paper mills, steel industry, and mining. Workers in these sectors are not highly incentivised to seek new job opportunities nor to pursue further education, as work-based training has generally been enough. However, this group is particularly at risk of long-term unemployment if dismissed from their jobs. Automation and other structural changes in the existing economy are in fact leaving many of such workers out of the labour market. According to Ejdemo \& Parding (2018), global, national, and regional trends indicate that large parts of certain professions in Norrbotten region will be affected by automation in different ways. LKAB mining industry, for example, is increasingly automating to remain competitive in global markets (ibid). This has already resulted in a decline in the demand for professions such as process operators within metal and steelworks (ibid). At the same time, the demand for engineers, technicians, and data specialists is on the rise (ibid).

Rapidly changing labour markets are not only a challenge for the low-educated segment. "Changes in industries is happening much faster than education systems' ability to adapt, sometimes even than education programmes" (Oulu employment agency). Therefore, even educated people are struggling with keeping up with the level of skills required in the labour market.

\section{Horizontal mismatch (sectoral - skills available are different from those needed)}

Horizontal mismatch is also present in the region. As one informant neatly puts it, "companies complain they can't find the right skills". Traditionally, the regional economy has been dominated by heavy industrial sectors, leading many people to these types of jobs. These are also said to be maledominated sectors leading more women to attain higher education than men, but then struggling to find jobs in the region. With the rise of the telecom sector, mostly in Lulea and Oulu, and the presence of the two large universities in the two cities, the labour market opened many new job opportunities outside the traditional sectors. Likewise, the public sector absorbs a substantial share of the jobs outside the traditional sectors. However, the faststructural transformation of the economy with automation and service sectors becoming more prominent, there are considerable differences between the skills gained by workers in the in the past and those in demand today.

\section{Other factors leading to skills mismatch}

Apart from vertical and horizontal mismatch, many other reasons can be identified to disrupt the matching of skills supply and demand. 


\subsubsection{Missing links between supply and demand}

The missing links between employers and jobseekers were some of the most common issues raised during interviews. Often there is not enough knowledge about the opportunities available. At the same time, many companies do not find or do not know how to search for the labour they need. As clearly explained by an employment consultant at Nordisk Kompetens, "it goes both ways, companies have trouble finding people, and people don't easily find companies". This seems to be particularly problematic for SMEs, which account for the majority of companies in the region, both in the Swedish and Finnish side.

According to Oulu business association: "most SMEs do not have an experienced recruiter, someone that knows how to head-hunt for skilled people". Many do not have a professional website that looks attractive for skilled professionals, or do not have one at all. Similarly, Swedish informants stress that companies can lack experience on how to brand themselves. Nordisk Kompetens suggests that to attract jobseekers, companies need to invite people to "walk around, see, and feel the environment within a company, so that they can see what is there for themselves, how can they develop professionally, and what are the company's values".

Being able to establish a link between employers and students was said to be particularly important to stop the drain of human capital built locally out of the region. Lulea business organisation (Näringsliv) recalls: "students often say that they would stay if there would be job opportunities, while unaware of the existing possibilities". Students and young professionals need additional support to enter the labour market; to get to know companies but even to identify what their interests are. For instance, Nordisk Kompetens facilitates the contact between students and companies. They bring them together and come with them to their first and even second meeting. After that, once the contact is established, then they let them go on their own, and stress that "this conversation would often not continue unless we bring them by 'holding [their] hand'".

The communication gap between employers and jobseekers, as well as all other actors relevant in skills development and governance, generates conflicting expectations between the sides. "Employers expect graduates to know everything" says one informant. Company owners also expect employees to be committed and work hard, but at the same time, younger generations are said to be more strategic about their career development beyond a specific job or employer. One informant noted that "young people demand more flexible working conditions and are not ready to take a job at any cost - they are picky to what conditions are offered".

\section{Individual factors \& motivation}

Personal preferences, social networks and socioeconomic background play an important role in people's choices regarding their career paths and whether or not they are willing to take a job. Aside from their skillset, individuals may be more or less inclined to take a job depending on what it represent in terms of their ambitions, the future it promises, the salary level, commuting distance, or whether there is a stigma associated to it or its company. People can have the perception that a given job 'is not good enough for them', or that the workplace is gendered mentioned different informants. Others may not be ready to move away from their place of origin or travel long distances.

Motivation was repeatedly brought up during the interviews as the key element driving individuals into action. Informants explained that motivation can be related to expectations, financial security or the extent to which individuals have been exposed to work and education opportunities. According to Nordisk Kompetens, "some work experience helps young people grow up; it reinforces their self-esteem and personality, which then boosts their willingness to learn and achieve something".

For those who were already integrated to the labour market but have lost their job: "motivation goes down very fast". The Swedish employment agency (Arbetsförmendlingen) provides many options, such as training or support with opening a business. One critical comment however hinges on that the support often comes late: "If someone is unemployed for 12 months they have no motivation to start their own business (...) they are more concerned of their next pay-check and satisfying their immediate needs than thinking about big ideas".

A teacher from Svefi, binational folk high school, explains that many of the students leave regular schools because they are unmotivated. Many of them have been unemployed or have no clear career expectations when they enter the folk high school. Therefore, the school provides stu- 
dents with different perspectives for them to find their interests.

Generous unemployment benefits are said to give some people little incentive to get back to work, according to interviews. However, financial gains may not be the sole reason to work for some. Attitude is, therefore, a key attribute companies are interested and "how they behave at work" one person says. Therefore, soft skills should not be underestimated when looking at the reasons behind matching employers and employees' expectations.

\section{Unemployable group}

There is a segment of the population that is often referred as 'unemployable'. This is a mixed group, that for different reasons is hindered from performing work tasks regularly or simply that lack the qualifications to perform certain job tasks. This can be people that have some kind of disability or illness that impedes them from working, or people with low self-esteem and severe depression. North Finland was mentioned to have a higher percentage of people with disabilities compared with the rest of Finland. However, informants stated that labour laws are not flexible enough to allow people with such limitations integrate to the labour market. For instance, "some could work a certain number of hours but not full time" according to an interviewee.

\section{Structural issues}

A number of structural factors were identified to be in the way of skills supply and demand. Administrative requirements for validating education attained in foreign countries is a key problem for integrating immigrants to the labour market. While the need of labour is great, many immigrants are downgraded to work with jobs that require a lower level of skills, because their titles cannot be validated in Sweden and Finland.

Moreover, the few education opportunities available in rural areas and small towns contrib- utes to an imbalance of the skills needed. Big cities are a magnet for high skilled workers. But also, people from the rural areas are attracted to cities even before they acquire an education, because of the few opportunities available locally. Despite the growing trend of distance learning in rural communities (Randallt al., 2020).

Therefore, by not being able to produce talent, rural areas lose people before they even try entering the labour market locally. Once leaving the rural areas, few of those skilled people chose to go back, even when there is a demand.

The rigidity of education systems was mentioned not to serve the specific local needs as the curricula is decided in Helsinki and Stockholm. One informant recalls that when asked to introduce a new course related to metal workers, the vocational school "told us that they would need to discuss it with the ministry and they could only produce the first graduates after 6 or 7 years".

\section{Cross border supply and demand}

Cross-border mobility fills some of the gaps between supply and demand in the Bothnian Arc. Yet the extent to which this happens is limited and difficult to assess accurately. There is no reliable knowledge or statistics about the needs across borders, and how many people cross the border daily to work or to provide a service. As an informant bluntly puts it "there is no place for statistics in cross-border labour mobility". Another informant adds: "we can ask the region or the municipality, but they can just guess". According to the employment office in Kemi, "we have statistics of people living in Kemi and working in Tornio, but if you are living in Kemi and working in Haparanda is different". However, developments in different industries provides some indications on what kind of labour is needed that can be complemented across borders. For instance, big investments in bioeconomy and growing tourism give an idea of what kind of jobs are being created. 


\subsection{Mobility}

Labour mobility across borders and beyond the Bothnian Arc region can be a mechanism of satisficing the labour market needs. However, empirical fieldwork in the Bothnian Arc region shows that the labour mobility is seemingly not being used to its full potential to fill labour market gaps. Increased integration of the labour markets in either side of the border promises fruitful results for the entire region.

\subsubsection{Beyond Bothnian Arc}

Labour mobility beyond the Bothnian Arc region is both an opportunity and a threat. While brain drain is a form of labour mobility playing to the disadvantage of the region, there is also an opportunity to attract people from all parts of Sweden and Finland and from abroad into the region. According to several interviews with regional and municipal authorities, tackling demographic decline and the lack of labour is a big political debate. A researcher at LTU adds: "we need to recruit people from abroad, we cannot expect that enough people will move from other parts of Sweden [to Norrbotten] because [those regions] will be facing the same demographic challenges as us". However, while labour markets, and particularly those far from the capital regions desperately need new workers, interviewees note that growing antiimmigration sentiments at national levels pose a major barrier for using this opportunity. According to interviewees, the regions do not have a strong representation in Helsinki or Stockholm and are, thus, at the behest of decision-makers who often lack the perspective of the northern-most regions.

Despite the less welcoming sentiments towards immigrants at the national level, the Northern regions have wealthy economies and many jobs to offer. With major migration flows towards Europe, EU countries and regions have to receive a quota of refugees and economic migrants. An informant from the employment agency in Northern Ostrobothnia noted that on the day of the interview there was "a public event for companies to learn about those immigrants, some of which are actually high skilled" (Employment agency Northern Ostrobothnia). Highly skilled workers, both citizens and immigrant, normally do not seek support from the employment office, but search for opportunities on their own. Validation of foreign education degrees or professions are, however, a major barrier for this group. An informant notes that "many of those coming from abroad cannot use their skills because they do not have a valid certification to work in Finland", and therefore, their human capital is being wasted.

Mobility is also a threat to the region's labour market as there is a strong negative demographic trend today. A researcher at LTU notes that "Norrbotten loses a lot of competences from people who are educated here and then leave". Similarly, a researcher at Oulu University corroborates with this point as in North Finland "many more educated people move away than those coming in". "We are exporting talent" she emphasises.

Housing costs, liveability, and security are some of the factors that play a role for people to move out or into the region. Housing is expensive in cities like Helsinki, Stockholm, and other major cities, which stops some people from moving away, particularly low skilled workers. According to a researcher at Oulu University, "some people do not move to Helsinki, even though there are many jobs, because it is expensive to live there". Moreover, most locals appreciate the nature, the 'real winter' and the safety, which are decisive conditions for many to stay in the region. However, the same real winter and darkness can be a reason for outsiders to think twice before moving there.

Recreation and cultural amenities and particularly an international environment, are key for those coming in with their families. Discussions on establishing an English school in Luleå have recognised this and seen its potential for attracting new people. Comparably, in Oulu, the international school provides opportunities for many families, not only to newcomers, but also to locals who wish to expose their children to an international environment. For this reason, the informant from Luleå Business Organisation emphasises the importance to work with 'soft-landing' for families and notes that "most municipalities have some funding to support the settling process for people, their families and children". 


\subsubsection{Cross-border mobility}

According to interviews there is quite a potential for cross-border labour mobility. To a large extent, the labour markets appear to be quite similar in terms of the types of industries and jobs available. Both North Finland and North Sweden have a long tradition with process industries such as paper and pulp, steel, and metal, as well as mining. Likewise, they share other similarities in the tech sector, tourism, and academia. Moreover, similar climatic conditions and lifestyle make the move from one side of the border to the other relatively easy.

Labour mobility across the border fills some of the gaps in the demand for skills. For instance, LTU and Luleå municipality were said to be quite agile in recruiting professionals from Finland. Teachers and nurses are some of the professionals that are most actively head-hunted by the local authorities in Luleå, but also lower degree workers, such as electricians and builders. LTU is active in their search for academics and IT experts.
Nevertheless, the opportunity to complement the labour markets across borders is not being taken to its full potential. Most initiatives are ad-hoc, and typically respond to emerging needs, rather than existing as a continuously coordinated effort (See Box 1). For instance, Business Oulu organised a project to get people to move across the Northern parts of Finland, Sweden, and Norway to work with cleaning, fishing factories, and other mostly seasonal jobs. However, this is an initiative on a relatively small scale, and seasonal workers often change every year, according to interviews. Oulu Business association instead explains that they "do not work with attracting skills from abroad, but companies do it themselves". For instance, some companies, such as LKAB, 'fly-in-fly-out' specialised professionals. Instead, other companies have opted for distance work to access labour that would otherwise not be possible to find. For instance, an interviewee refers to an IT company based in Raahe that "does not have an office anymore, so employees work from anywhere else".

\section{Box 1. Employment for companies' growth in the Bothnian Sea}

In 2017-2018, the Employment Agency of Northern Ostrobothnia led a project titled 'Employment for companies' growth in the Bothnian Sea'. The aim was to generate knowledge about the labour market needs and cooperation across the Bothnian Arc to establish new business networks and boost labour mobility. As a first step, the project assessed the labour market needs, the state of cross-border mobility and identified companies willing to expand. Data was collected on the number of people crossing the borders for work. In doing this, they could not to rely on the official statistics because they provide a limited picture and are based on administrative units. Instead, this work considered labour markets beyond municipal boundaries and permanent crossings.

As a second step, concrete steps were taken to facilitate cross-border labour mobility, particularly in the construction sector and metal industry. This effort proved to be more difficult than expected. Some of the challenges identified included:

- Different recruitment practices and requirements

- Lack of awareness of the opportunities

- Social relations and networks, and the lack thereof, play a role in getting new jobs

- Cultural and language differences

- Attitudes and perceptions of the neighbouring country

- Attitudes towards moving away from home, or to a place in particular.

A second approach in the project was to establish business relations between companies in both countries. One concrete effort was to show the opportunities in sub-contracting companies from the neighbouring country when companies do not have the capacity to take a work offer or part of it. This approach proved promising. However, the results achieved were limited due to the short duration of the project. Still, a positive result was that companies became more aware of the opportunities. Additionally, there is more openness from companies to expand their activities to either side of the border. 
Sometimes recruitments are very targeted. For instance, in "big infrastructure projects taking place in Northern Norway and Northern Sweden, within energy, traffic and tourism sectors". An official from the city of Oulu explains that building companies "have been in Oulu several times recruiting, not just engineers and highly educated professionals, but lower degree, vocational professionals, electricians and so forth".

A more systematic effort for labour mobility, is the so-called 'Arctic Five' collaboration between universities in northern Finland, Sweden, and Norway to boost exchange between academics (see Box 2).

\section{Challenges:}

In spite of the opportunities available, many recruitment efforts across border are not successful. Some challenges for cross-border labour mobility in the region have to do with personal barriers such as comfortableness in the home area and practical mobility issues such as money and time costs of travelling by car. Navigating through administrative issues such as different tax schemes or social security systems also plays a role when moving across national borders. Additionally, mobility is largely unidirectional from Finland to Sweden. This is said to be case due to historic and cultural reasons. Having been under the Swedish rule, Finns are more accustomed to the Swedish influence and language. Also, "there have been big waves of Finnish people moving to Sweden for work, and so many people have friends and family there" (Researcher at Oulu University). This makes it more natural for many Finns to make the move, especially when having family and other connections in the country. The opposite direction may thus seem less natural. Swedes are not nearly accustomed to the Finnish language and three may be fewer connections to the country. Informants have also pinpointed perceptions that "opportunities are not to be found on the East, but on the South and West".

Similarly occurs between Northern Norway and Finland. According to a researcher in Oulu "there have been initiatives in the past promoting people to move from Finland to Norway and vice versa, but it is not so easy to get people moving, possibly because of the language difference". Yet, Finnish workers are attractive to Sweden and Nor-

\section{Box 2: Arctic Five: mobility of academics in the Northernmost regions}

'Arctic Five' is a specific initiative to promote the mobility of academics between the five universities situated in the Northernmost part of the Nordic Countries. These Include UiT, the Arctic University of Norway, Luleå University of Technology, Umeå University, the University of Lapland, and the University of Oulu. The Arctic Five collaboration contribute to a better understanding of the contextual and cultural issues of the Nordic educational features via engagement with local communities, indigenous and minority populations, and through institutional and research collaborations. The aims are to build a concept for collaboration in teacher education in the global Arctic context: to map out and share the expertise and establish joint curricula.

With the 'Arctic Five' collaboration academics can find job opportunities in a similar setting to where they leave, often just a temporary working experience at another university, or even distance work. According to an academic, "this offers a great opportunity to circulate and create skills across the 'Arctic' regions and generate innovations". She also states that it has added value by "developing the regions and collaborating with companies".

According to various academics, it is hard to promote open positions to people in the South, as "they may think the North dark and cold, but for those already living in similar conditions it is easier". Therefore, the project helps the five universities advertise the open positions for other 'Arctic people', which are more likely to apply. Also, researcher rarely have long-term contracts, but are constantly in search for resources. This was argued to make them more likely to move across the five universities when new positions are opened. 
way. The same researcher explains, "many Finnish teachers and nurses have been attracted to work in Norway because of the generous salaries and laid-back working conditions".

Furthermore, many opinions suggest that there are underlaying attitudes in Northern Finland that disfavour cross-border labour mobility. For instance, there is said to be "a general negative attitude towards the Swedish language in this part of Finland". A researcher noted that there are many fewer expats in Northern Finland compared to Northern Sweden and Norway. The researcher believes that "there is a problem with the mindset of local people" that stop them from offering job opportunities to foreigners. In her words: "many students would like to stay and work, and even just for summer-jobs, but they find it very hard to find summer-jobs".
In this context, timing is a key factor in keeping or attracting young professionals. According to a researcher at Oulu University, "many studies, including our own, show that when you get married, and especially if you have children and buy a house, normally you are stuck". Another researcher adds that her recent studies show that "1 year after graduation, the spatial distribution of graduate students in Finland is quite stable". But immediately after the end of study programmes, graduates are highly mobile. Helping students integrate and establish themselves in the region during their studies is therefore very important in preventing them from leaving afterwards. However, one informant notes that "students mostly hang around the university, do not learn Swedish nor integrate into the city life - so, when [their] studies have finished, it's too late". In this context, researchers believe that companies play an important role in getting students interested in the opportunities locally, but they need to get students interested early enough.

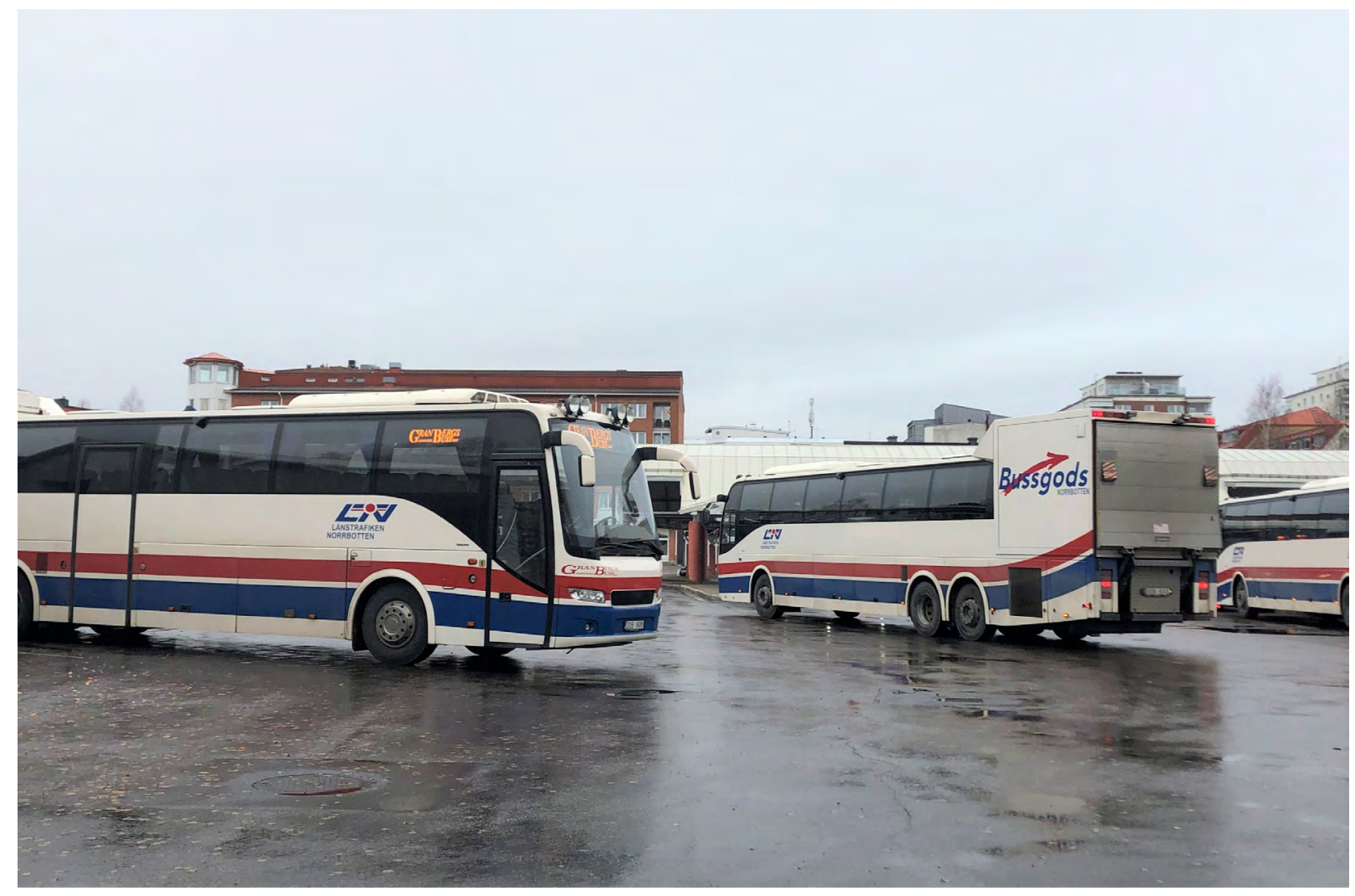

"Distance is another determinant factor for cross-border labour mobility". Photo: Alberto Giacometti 
Distance is another determinant factor for cross-border labour mobility. Many interviewees agree that while there is high cross-border mobility in the immediate border area, the number of crossings drastically drops with only few kilometres away from the borderline. According to one informant, the distance to the border from Oulu feels far, but says "when I was leaving back there [in the Tornio area], I went shopping every week in Sweden, so the mental distance is very different than here in Oulu". Another informant's opinion holds that " $20 \mathrm{~km}$ from the border you have one labour market, after that you do not - it's hard to think of Oulu and Luleå as a common labour market". However, different economic sectors or industries have different labour market sizes. For instance, the IT sector or academia have much larger labour markets compared to other sectors, with more people moving from Oulu to Luleå for work and vice versa.

In addition to the pre-existing challenges for cross-border mobility, the sudden appearance of the Covid-19 virus and the measures that followed, added a new layer to the cross-border barriers (see Box 3).

\section{Box 3: Covid-19 pandemic and the sudden border blockade}

For the first time in many decades the state border between Finland and Sweden became something more than a formal line, as a result of the efforts to stop the spread of the Covid-19 virus in the spring2020. This response does not match the ambitions of the new Nordic Vision of the Nordic Council of Ministers as 'the most integrated region in the world'. Fences were raised, cutting across the Victoria Square situated in the middle of the twin cities of Haparanda-Tornio. Barricades were placed on bridges, and the Finnish National Guard was set to control every crossing, if allowed.

The Covid-19 outbreak came as a surprise to everyone, but so did the responses to it. In the many decades of Nordic collaboration, cross-border mobility has never seen the like-. This may leave some scars in the cross-border community, which depends on daily or at least continuous crossings. Families were forced to stay apart, parents living in either side had to meet exactly at the border to get to see their children. "It was like the Berlin Wall went up across our town square" said the Swedish lawmaker Ida Karkiainen to Politico'.

In all this, no specific considerations were made to attend the needs of cross-border communities, says Birgitta Tamminen from the North Calotte Cross-Border Advise Service. The national agencies were quick to react to the issues brought up by the Nordic Free Movement Committee in collaboration with the border information points, states Claes Håkansson from NCM secretariat. Yet the damage has already been made. This has led to a big hole in the trust of the community to authorities in dealing with cross-border specific needs. It has also revived nationalistic sentiments, Tamminen adds. Some companies operating at either side of the border have stopped their operations, companies have relocated, and some commuters have lost their jobs. Rebuilding this trust will take time but will be essential for a more integrated society and labour market across borders.

\footnotetext{
${ }^{1}$ https://www.politico.eu/article/sweden-finland-norway-denmark-coronavirus-may-change-nordicfriendships-forever
} 


\subsection{Skills development}

With technology and industry changing at a fast pace, there is a need for adapting the skills in the labour market, as well as adapting the means for skills acquisition. The growing need for continuous learning calls for new relations between education institutions, companies and employers, and other actors relevant in the labour market. To an extent, this is already happening. According to a researcher at the University of Oulu, "there was a lot of focus on education as means to gain skills in the past, but now there is more focus on combining education and practice, bringing together businesses into education programmes". Moreover, emerging digital solutions provide more opportunities for distance learning, which entails a partial shift in responsibility for skills development to individual professionals. While this requires a great deal of self-drive, it is also an opportunity for empowering and for democratising knowledge acquisition and spreading opportunities throughout the territory.

In this context, field work in the Bothnian Arc cross-border region provide some results regarding: the role of educational institutions, the role of companies and employers, the links between different actors, and the dynamics around lifelong learning or the continuous process of professional development.

\subsubsection{Role of education in skills development}

Formal education plays an important role in raising the foundational skills in the region. Moreover, universities in Luleå, Oulu and Rovaniemi generate a solid ground of specialised skills through the formation of a wide range of professionals. The universities also play an important role in generating knowledge through research and boosting the innovation system. Several informants agree on the presence of high-level education across many fields, on both sides for the Finnish-Swedish border. The long tradition of large process industries and telecom firms, and more recently space and other highly scientific industries, has inspired a generation of engineers, scientists, and IT professionals. On the flip side, the number of school dropouts is relatively high, with many entering the labour market at young age without pursuing an education. However, structural transformation in the economy has left many industry workers unemployed and unfit to undertake different jobs. Therefore, greater emphasis is placed on voca- tional education as a means for reducing the mismatch between supply and demand of skills in the region.

Vocational education plays a major role in generating skills for the region. Several interviewees note that the scale of influence of vocational education is often forgotten or minimised compared to academic education. Nordisk Kompetens highlights that "Vuxenutbildningen [adult education/ vocational training] is one of the biggest educators in Luleå". Moreover, compared to academic education programmes, vocational schools provide a great deal of flexibility with tailored training according to specific needs and making it possible to combine work and study. The employment agency in Kemi explains that "anyone can contact the school and tell them what kind of skills they have already and what new skills they would need". Vocational education can serve both to form new professionals and re-skill active workers. The Swedish Finnish (SVEFI) 'Folk High School' represents a unique example of practical education stretching from high-school to adult education, located at the border cities of Haparanda-Tornio (See Box 4)

Academic education is generally less flexible. Students may have some possibilities to choose from different courses, but studies are rarely combined with relevant work. However, doctorates and researchers do work in close connection with business and other activities outside the academic sphere. According to a project leader at LTU, the university has extensive collaboration with companies in the region, with a substantial share of the research being financed by them. Similarly occurs with Oulu University, which has a strong presence in the regional affairs and business networks.

A major challenge in the primary and secondary education system is that there are not enough professionals, and there are different standards in teachers' formation in Finland and Sweden. Finland has high requirements and standards to become a teacher; teachers possess a solid mastery of the subjects they teach and teaching is research based (Sahlberg, 2015). According to one informant, these standards are lower in Sweden. In their words, "Finland has very good teachers, they are required a master's degree, in contrast to Sweden, which requires only a bachelor's degree." Apart from a general deficit of teachers in Sweden, the high quality of Finnish teachers has attracted the attention of Swedish municipalities. As the same 


\section{Box 4: Svefi - Swedish Finnish 'Folk High School'}

Svefi, is a binational - Swedish Finnish 'Folk High School' located in Haparanda by the SwedishFinnish border. The school provides opportunities to students in both countries beyond what is offered by regular schools. As all other folk high schools in Sweden and Finland, Svefi is a hybrid type of school, which provides general education but also a range of tailored courses in many fields, for both high school students and adults. The school aim, according to its website, is to "provide stimulating and developing popular education, whether it is to strengthen upper secondary education, develop within a specific area of interest, occupation, or gain personal stimulation and development" (https://svefi.net/ Access: 15.05.2020).

Svefi runs several pedagogical projects to serve the specific needs of its students. For example, the school attempts to support young people who lack a clear career path or motivation. The school offers them coaching and orientation along with different activities to connect them with the labour market. According to Göran Mukka, teacher at Svefi, "the courses are tailored for the needs of every student". For instance, Mukka "worked in project for three years with cross-border issues related to young people (education or employment) but beyond Tornio or Haparanda". Mukka notes that those who live near the border often think that crossing the border requires a huge effort. Therefore, he adds "we try to get the young people to visit different schools and opportunities in both countries to raise those barriers".

Mukka believes that Svefi is having an important role in raising the skill levels in the community and making the opportunities across borders more visible. For instance, he explains that "when we start a new training course, we get in contact with the employment agency and they provide us with the students who are interested in working with it". In this way when they have finished school they can be put to work directly.

The school is also a space for a wide range of events, from conferences and cultural events. Svefi participates also in the development of the local community through various collaborations and projects.

interview puts it: "Luleå is very keen to recruiting Finnish teachers; they are ready to teach them Swedish language and support them because they appreciate their high-level of education".

Another major challenge with education, is the growing relevance of other actors in skills development, and the importance of life-long learning. More on this is elaborated in the following sections.

\subsubsection{Role of companies and employers in skills development}

Education institutions are not the only actors in skills development. Companies and employers generally, play a key role in delivering training that is of specific utility for that workplace. Some skills are known as firm-specific as they are tied to a particular firm (Busemeyer \& Trampusch, 2019) and may not be useful in other firms (Muehleman, 2019). In such cases, the firm needs to provide the employee with the necessary training to be able to perform their work-tasks. For example, an official from Oulu city notes that many IT companies are lacking enough skilled professionals, both because of the high demand for these skills, but also because of the high degree of specialisation needed. In his words:

"Oulu has very specialised companies and innovations within IT-health, IT-wellbeing, IT-environment, Al, 3D-printing. They are lacking labour even though the University has increased the number of students in IT and engineering. So, when they find a good person, they take them and train them even for very specialised tasks. Such narrow skills, for instance, universities cannot provide". (City of Oulu)

While universities provide a more general education with a focus on long-term needs, employers are more focused on the market trends and the immediate skills needed. According to Norrbotten's Chamber of Commerce, "some of the big- 
gest companies know how to attract knowledge, they are more strategic in their thinking than the public sector". The chamber is involved in various activities to "analyse market trends, and business ecosystems, clusters and innovation systems, also connected to research". Following market interests, companies are proactive in research and development of new technologies and products. In this innovation process they need to build skills internally through continuous training. On the Finnish side informants depict a similar picture, where larger companies provide significant training, "for instance when new equipment is acquired, workers need to learn how to operate it" (Northern Ostrobothnia Region).

However, skills development at the workplace can hardly be generalised. The IT sector and other global companies in the region are described as highly dynamic and rapidly changing. The skills needed for these industries have to follow technological and other transformational trends closely. Yet, while these companies are dominant in the region, the majority of employment is allocated in public sector and SMEs. Many of which, experience slower transformation and are less dependent to the latest technological innovations.

In this light, rigorous and systematic training at the workplace is mostly present in large industries and firms, and in specialised public sector areas, such as health care. Whereas most SMEs do not have the capacity or resources to offer such opportunities to their employees and training is more ad hoc. The same was said about employees in other public sector areas, who not always receive training at the workplace, such as teachers and civil servants. According to Oulu Chamber of Commerce, "the problem is giving people what they need without having to go through an entire education programme". They argue that companies cannot send away their staff to acquire a full education, but they would benefit of getting "just that piece of knowledge or skill". Therefore, money is not always an issue. They believe that there is a structural problem with the education system, which is not ready for reskilling workers through their professional lives.

\subsubsection{Lifelong learning}

Skills development is not a closed cycle - with a clear beginning and an end - but rather a continuous process through professional life and beyond. Once the formal period of education is completed
- be it primary, secondary, or tertiary education - companies and employers play a dominant role in skills development. Employers have the power of generating an enabling or obstructive environment for skills acquisition and personal growth. A researcher at LTU points out that "skills-development needs to be integrated within the organisation's daily work - and followed up, to ensure that there is a change in the internal procedures, and ways of doing things". Education has also a role to play in continuous education, even though many are of the opinion that the education system today is too rigid and lacks opportunities for active professionals. Some possibilities for attaining a more tailored education opportunities are to be found in 'Folk High Schools' and vocational adult education. Academic education tends to follow more strict curricula.

Formalised strategies and mechanisms for lifelong learning are rare. However, certain specialised areas within the public sector have established mechanisms for this. One example is the medical sector where doctors must spend a percentage of their working time updating their skills: "In dentistry for instance, they have to do practices in 'phantom laboratory' where they do simulations'" (City of Oulu). Other public sector positions also allocate time for professional development without imposing specific requirements. This time can be used in different forms of education such as courses, seminars, or distance learning. However, such activities are not often anchored to the work tasks or influenced by the professional who is receiving this aid. A researcher in LTU notes that "we often go to very fancy conferences or one-time training, which are generally ineffective - we go back to the office the next day and it is all forgotten". The researcher adds that other forms of internal training are not always prioritised because they are not easily measurable. In her words "if I show I have gone to 3 conferences, it is easy to quantify, but we held internal workshops or spent extra time in discussing certain issue, then it is hard to measure the impact". Therefore, there is a need for 'thinking more about work-place competence strategies" the researcher concludes.

According to several informants, many people in Northern Sweden and Finland have outdated skills. The employment agency in Northern Ostrobothnia attributes part of the reason to the structural transformation of the labour market. In their words: "changes in industries happen much 
faster than education systems, and even faster than education programmes". These changes are affecting some of the local industries more radically such as the paper mills and IT. However, the degree of adaptability between workers in the two industries is rather different. Workers in in the paper and other process industries are not updating their skills as much as other industries.

"People have very good salaries in the paper industry, even low-educated people - and they are really at risk of losing jobs [because of automation], but they are not incentivised to change jobs, because of the good salaries" (Interview).

Similarly, across the Bothnian Arc region there are many workers, who have started their working carriers early and are not prepared for taking other jobs.

The many global companies in the region are leading in technological innovation. This secures the competitiveness of the region and brings new business opportunities, while at the same time it threatens workers that can be left without any relevant skills to stay active in the labour market. Norrbotten's chamber of commerce explained:

"We have very interesting developments in 'the space' sector, in steel technologies with a new way of making steel with minimal carbon footprint, we are developing an autonomous mine; and we need to make sure we find the competences we need for these developments even if from outside"

Automation and technological development are putting pressure on the labour market, and often leaving it to the individual to catch up with the changes. A researcher in Luleå emphasises that companies investing in their skills development are not only better prepared for future needs and challenges but are also securing the long-term employability of their staff.

\subsubsection{Links between employer and employee}

Skills development is of importance to all actors in a region, including companies, employers, the public administration, and the individuals. Also, as elaborated in previous sections, different actors play a role in skills development. However, there is little coordination between employers and education institutions in defining education outcomes. For instance, the employment agency in Northern Ostrobothnia stresses that "often, there is not enough understanding of what companies need". While at the same time, employers many times have unrealistic expectations on graduates. According to the employment office in Kemi, companies often expect 'human-robots' that can replace employees in retirement age with 30-40 years of experience. Unrealistic expectations often reflect the lack of understanding of how skills are developed. As Nordisk Kompetens points out: "there are differences between the skills we gain at school and the workplace - often those at the workplace being more practical."

In this context, the links between education, employer and employee are pivotal in generating understanding of each other's role and coordinating skills development. Most often employers and employees find each other directly, and otherwise the employment agencies and consultants facilitate the 'matchmaking'. Additionally, universities and especially vocational schools establish links between employers and students. Not always, but in certain cases, these links also involve coordination in skills development. Employment agencies in Sweden (Arbetsförmedlingen) and Finland (TE) do not only work with matching companies' demand with labour supply but providing mentorship to newly employed workers. When companies request candidates for their positions, Arbetsförmedlingen assigns the candidates a mentor that will work closely with the company to evaluate the candidate's progress and to ensure the acquisition of skills. This cooperation turns fruitful in that unemployed or young people have access to on-thejob training that can upgrade their skills (Reed example in Box 5). 
Box 5: 'Idol competition', training and mentorship: a coordinated effort to integrate young adults to work and support their skills development

Few years back, Mariam Al-zamami and Jonny Häggström, teamed up with KGS AB - a subsidiary company LKAB, Sweden's state-owned mining company, to incorporate unemployed young adults into their company. At that time, the two colleagues where testing different ideas for how to raise and retain skills in Norrbotten region. The two then established Nordisk Kompetens, an employment consultancy.

KGS AB and LKAB employ a numerous people in the region and require a range of skills to carry out their operations. However, unable to find all the skills they need locally or attract professionals willing to relocate, the companies often hire services from outside the region, in a 'fly-in-fly-out' (FIFO) modality, which requires flying in professionals for short periods at the time. For instance, "they come in, work 7 days, then they fly back home for another 7 days, and so on" according to an interviewee. At the same time, there are many unemployed young adults in the cities of Kiruna and Gällivare where the mines are. Yet, they do not have the necessary training and education the companies need.

Therefore, Arbetsförmendlingen was asked to identify potential candidates, and together they organised some kind of 'idol competition'. The intention was "not just giving them easy money, but to getting them interested and show interest in the work in KGS". From this competition, four candidates were selected to work as interns at the company. Each of them was assigned a mentor and was evaluated every week. The evaluation included four different parameters. If they scored high in all of them, the company would hire them. Once hired, they would keep their mentors to ensure further progress.

Eventually, from the four candidates chosen, two of them were directly hired to KGS, one of them was hired to another LKAB sub-company, and the last one went back to school to attain an education in the profession and was later on hired into the company.

According to Jonny, this was not only a success from the perspective of the company, but for the regional interests as these people would have otherwise moved away seeking for opportunities elsewhere. What is more this is an example of skills development by joining forces amongst regional actors outside formal education. 


\subsection{Skills governance}

Education is the formal responsibility of state municipal and national authorities, which in turn delegate to education institutions. However, from a broader perspective, relevant players on the skills system include: "all institutions and individuals, as well as policies, laws and regulations, concerned with the development and use of skills in the economy" (OECD 2020). Aside from the formal responsibility of state and local authorities in governing skills development and the clear role of education institutions and companies in skills development, there are a multitude of actors that play a role in skills development, as well as the different spaces and platforms for skills creation and circulation.

Companies, for instance, are key in attracting talent and funding research aside from training their staff with the skills they need. Moreover, in between key actors, there are many other players, such as employment agencies, municipal associations, chambers of commerce and other types of business organisations, consultants and so on. Some have more or less clear roles in skills governance, but the links and collaborations are mostly ad hoc and related to specific issues, rather than comprehensive and systematic (Lundgren et al 2020). These actors, however, play an important role as intermediaries.

This section is not meant to provide a comprehensive picture of skills governance in the Bothnian Arc nor a complete mapping of actors, but to address some of the key insights and examples that emerged during interviews with local actors.

\section{Should authorities or companies adapt to trends?}

Given the demographic situation, the regional and municipal policies have a strong focus on attracting new people. Yet, an informant from Norrbotten's Chamber of Commerce, is sceptical of whether this is having any meaningful impact, when the figures show that population levels has barely changed since the 1950s. He believes a different mindset is needed, "we cannot expect people moving in - life in the north is demanding and not many want to move here". Therefore, in his opinion, policy should focus on attracting talent without requiring workers to physically moving there. He refers to a recent visit to China where he learned that talented people from all over the world work from distance in their universities and science parks. Companies in Norrbotten, he explains, have set clear goals and are leading the way in many global trends. "SSAB will soon be able to produce steel with a minimal carbon footprint, self-driven cars are being tested, and hydrogen is being extracted and waiting to be used (...) But instead the public sector is not there, is too slow" he concludes.

Another interviewee is of the opinion that "companies need to change their ways of working and thinking when it comes to competence supply. They need to work with skills in a broader perspective. They need to find ways to by-pass challenges such as language, location, lack of certain skills". To him, "companies should not expect that the municipality or universities will solve their [particular] needs; they need to find solutions". Distance work, for instance, comes as an obvious solution. Interviewees stress that distance work has been there for a while, and now it is simply a necessity. Oulu Business association notes that "many companies would like to keep the people in their office, but do not have an option - so companies need to change". Additionally, another informant notes that employers need to understand what makes their workplace attractive, what makes employees motivated to stay, or even relocate.

In contrast, interviewees from Norrbotten Region are sceptical about leaving it to companies to find their own solutions on skills development. They recognise that globally leading companies will "try to be at the front of innovation and technology, but when it comes to educate workers and skills, they do not know how to address it". Essentially, they denote that companies are able to train their staff in specific technical skills but are not capable of providing a comprehensive education.

\subsubsection{Regional and municipal authorities \& col- laboration}

Regional authorities do not have a formal role in education, while municipalities finance schools and vocational schools, and runs the employment service. In Finland, municipalities are responsible to finance unemployment allowances, therefore they have a strong interest in bringing people back to work. In doing so, upscaling skills is a direct way of enabling employability (Employment service in Kemi municipality). In Sweden, unemployment allowances are coordinated at a state level by the Swedish Social Insurance Agency - Försäkringskassan, nevertheless, municipalities are the main recipients of income tax, and therefore interested in keeping people employed. 
More informally, municipalities and regions also have an influence through activities and collaboration with other key actors in multiple constellations. The cities of Oulu and Lulea, for instance, work in close collaboration with their universities, which is payed and regulated at national level, "but heavily influenced by the city of Oulu" and likewise in Luleå. Some of these collaborations are more formally constituted, such as "Oulu Innovation Alliance, [which] is an agreement between the city of Oulu, the region, the University, university hospital, research centres, applied sciences, among others". In Norrbotten, a specific task force was established to coordinate actions on skills development and governance amongst several regional actors (see Box 6).

\section{Box 6: Norrbotten's regional competence council}

Norrbotten's regional competence council is a task force between key actors in the region to coordinate actions on skills development and governance. The task force is made up of municipalities, employment service: Arbetsförmedlingen, Region Norrbotten (the County Council), the County Administrative Board (Länsstyrelsen), Luleå University of Technology (LTU), and vocational education schools.

The regional competence council meets up every four months to discuss various issues regarding skills coordination. The collaboration has set four key tasks to work on together: 1) to analyse and look at labour market prognosis; 2 ) provide and coordinate adult and vocational education in all municipalities; 3 ) establish regional structures for validation and recognition of previous learning; and 4) stimulate and support the development of Distant Learning Centres (lärcentrum) throughout the county.

The first task consists of conducting short-term labour market forecasts with the support of LTU. The second task consists of coordinating efforts between authorities and businesses. This is challenging because companies do not seem to have enough awareness of the efforts in place on skills and have little time at their disposal for such activities. Therefore, this task relies, to a large extent, on the input from business member organisations such as the Industriellt Utvecklingscentrum (IUC) - or - Industrial Development Centre, with small, medium, and large member companies. One way this collaboration has materialized is via the funding for skills development projects provided by the Region Norrbotten. One topic that has been addressed through these projects is the heavy gender imbalance existing in the region. Region Norrbotten has promoted more women to be hired in industrial jobs, which are normally male dominated, by allocating funding to such practices.

The third task has been carried by the adult education schools in the municipalities, which provide vocational education and courses preparing for university entrance exams. To some extent, these schools validate previous learning for people with experience in an occupation but who have not had access to formal education. However, there is significant room for improvement regarding validation opportunities (Region Norrbotten). A certificate is provided to those who have completed the validation requirements, but this still involves going through an education. Interviewees from Region Norrbotten state that, for example, "carpenters have to take courses even though they already work as carpenters". They acknowledge that the adult education schools play a central role throughout the county, however, smaller municipalities often lack resources to provide this service. The regional authorities are therefore seeking to find an agreement with bigger municipalities to help the smaller and more remote ones.

Finally, the fourth task is to support the growth of Distant Learning Centres (lärcentrum) throughout the county. This is a physical place where adult students can access both vocational and university courses on a distance and also receive support from teachers and tutors. The development of these environments is particularly important in a region like Norrbotten with a sparse population and a vast territory. 
Furthermore, regions are responsible for coordinating the allocation of EU funds for regional development, which indirectly mobilise skills circulation, "for instance in guiding those who are interested in applying for European Funds". This in turn help to establish projects and collaborations with other actors across Europe, serving as platforms for knowledge exchange. Regions also work strategically with regional innovation and business competitiveness, assessing local and global trends and consequently the needs of the regions. Northern Ostrobothnia is the region with the largest EU funds. Together with other key actors a discussion has being taken up to address the role of lifelong learning as means to overcome some of the challenges with skills demands.

\subsubsection{Employment agencies}

Employment service plays a major role. Both Sweden and Finland have a designated national agency to deal with employment issues, which are most often interlined with skills in the labourmarket and individual persons. The Swedish Public Employment Service (Arbetsförmedlingen) is a government agency under the Ministry of Employment. The agency is responsible for employment services, the implementation of labour market policies and coordinate unemployment benefits with Försäkringskassan (the health insurance authority). The agency's subsidiaries throughout the country facilitate the contact between employers and job seekers. In doing so, they often come across the need for developing, upscaling and validating skills. Similarly, the Public Employment and Business Services in Finland (TE) operating under the Ministry of Economic Affairs and Employment is responsible for a functioning labour market "by ensuring the availability of competent workforce and by improving jobseekers' employment prospects and employability". In Northern Ostrobothnia, the "the employment office is a big unit with some 30-40 people working there and is particularly important in supporting those who have been under long-term unemployment" (Bothnian Arc Committee). They also provide courses for unemployed people to acquire new skills, such as digital, computer, language, as well as practical help with job applications.

Employment agencies work primarily with jobseekers in helping them identify potential employers. A few informants criticise this approach as it is not sufficiently taking into account the whole picture of career development and labour market needs. Employers often complain that they get numerous applications from people who do not fit their job profile. Therefore, some argue that a closer collaboration with companies is needed, for employment agencies to be better equipped to meet company needs and work together to identify the right people and develop the skills required. This view is shared by an informant working at the employment office for Northern Ostrobothnia. In his words, "TE should be talking more to the companies and know better what they need". However, he identifies two major impediments for adapting the way they work. Number one is that the national government defines the framework for how the TE offices work, and that the "structure can sometimes be too rigid for the local needs". And two, that "the local bosses have not prioritised it [working with companies], they prioritise only the work with the unemployed people". He acknowledges that to some extent the national guidelines leave some space for manoeuvring, but the lack of interest and resources have not made this possible.

Another challenge that the informant at TE identifies, is that government support or structural issues become available only temporarily in times of crisis. In his words: "when there is a big crash, then resources are made available for structural change through ELY-centre, to put the fire out. But otherwise that money is not available to continuously monitor the state of things".

Nevertheless, the TE office provides key services and is active at different fronts. According to a Business Association, "TE does a very good job, and they are the government organisation that visits companies the most, they really visit companies often".

They participate in fairs and are visible in vocational schools, where they inform about the opportunities locally and possible international experiences. The also collaborate with regional, local authorities and business associations. The TE also has a person within the agency that supports labour mobility across 32 countries as the contact person for EURES - the EU network for facilitation labour mobility.

Employment offices in Sweden and Finland also provide courses for people who need training or want to change career. 


\subsubsection{Business associations}

Industry, business member organisations, and chambers of commerce play a role in pointing out industry needs and facilitating employment and knowledge exchange. Through direct contact with businesses, as well as in more systematic ways, they assess market trends and labour market needs. Therefore, they are in a key position to inform regional authorities of what skills and competences are needed and should be developed.

Pohjois-Pohjanmaan Yrittäjät, an association of entrepreneurs in Oulu arranges some 100 events every year, which "are all about networking and learning". Depending on the event, they "have from 20 to 300 attendants in each event". According to the CEO, the events are not only for companies to get new employees, but for networking among entrepreneurs and learning from each other. They may also receive support on digitalisation, financing, and legal advice.

On few occasions, they have also "organised MBA programmes for entrepreneurs in cooperation with Oulu University". Entrepreneurs were able to carry on the programme alongside work, as they have to attend a few times per month and then do homework. They have also organised other types of programmes for entrepreneurs through the University of Applied Sciences, which "were more tailored, for instance to help SMEs and entrepreneurs grow". These courses have had a significant impact: "Last year, some 3000 people from different ages attended these courses."

The association of entrepreneurs as well as Business Oulu, also work in close collaboration with Ely centres, employment offices and regional authorities regarding strategic issues. The region often approaches them seeking information that can be useful when designing strategies and programmes for regional development.

Business Oulu provides employment services and collaborates with TE in recruitment strategies. One of these is matching events where companies and jobseekers can meet to fill in the opportunities available. Business Oulu and TE centre collaborates in recruitment events. For instance, they had a 'mega-matchmaking' event for companies to show the opportunities and recruit people, and for people in general to get informed of what opportunities are out there. Additionally, other "smaller events have been designed for a specific sector, for example IT, where many companies came from other palaces to recruit".
On the Swedish side, Norrbottens Handelskammare (chamber of commerce) works mostly with larger industries engaged in international trade, infrastructure, and competences. In their words, "we do not intervene in education - but we provide a network and work with future leaders". For instance, they have 'get-together seminars' with future leaders pin-pointed by member companies. These are individuals below 40 years old and from different sectors who meet once per month: "The idea is mostly that they create a network". Other than that, the organisation plays an important role in lobbying governments, generating awareness about industry's needs and business opportunities. For instance, they are carrying out forecasting analyses of industry's needs, which then gives them a base to push governments to move in a certain direction.

\subsubsection{Companies and employers}

Companies themselves, can also influence regional and municipal authorities or participate in more direct forms in attracting skills and developing skills. For instance, one informant recalls a past project in which the municipalities of Luleå, Boden, Piteå, Kalix and Älvsbyn organised events in Stockholm to lure people into moving up to Norrbotten, but it was not effective until companies took part. In her words "it was enough that the public authorities promote the region - we needed the companies to be there and show what job opportunities there are". Once the companies joined following events, some people decide to move in. Moreover, many and particular global companies, make recruitment efforts on their own to attract talent from abroad. According to Norrbotten's chamber of commerce, "some of the biggest companies know how to attract knowledge, they are more strategic in their thinking". In many cases, these efforts occur in their neighbouring regions and countries. The same informant adds, "most companies, if they go abroad, the most natural places are Norway and Finland. Then, 3rd and 4th [most popular] markets are Germany and the UK".

Companies can also play a pivotal role in skills retention by preventing students to leave the region after graduation. According to various informants, companies need to engage students already during their studies, show them what opportunities they have to offer and build relations. This, according to a researcher at LTU is the way to "make it obvious that 'we want you' - you should 
stay here". On this regard, the business school at Oulu University is trying to implement written "agreements with companies, so that they take interns every year from the business school". A professor at the Business School explains, that this is especially important for foreigners who do not have any contacts or the language skills, while "in this way they can more easily be connected to real life experience".

Finally, companies also play a key role in skills development directly at the workplace, in collaboration with vocational schools, employment offices, or consultants, as well as though research and development. Companies have large investments in research at the universities of Oulu and Lulea where PhD candidates and researchers develop new knowledge and skills.

Companies can impose standards on skills as a way to exert power on skills development. For example, SSAB introduced a requirement of at least high-school level to its employees. In the past a vast number of employees did not pursue an education, which would become a barrier in their carrier development if they were to change jobs in the future.

\subsubsection{Other actors}

Furthermore, a range of other actors play their part in facilitating skills supply or assessing the regional needs of skills.

Nordisk kompetens, an employment consultant, work with business development, competences, employment support across the regions of Norrbotten and Västerbotten. "We look at this through different angles and the different groups that need to be tackled differently". Namely, students, 'new Swedes' (immigrants), unemployed, and carrier development (those employed but need to develop their carrier). All these different groups need to work with skills development in different ways, from building skills from scratch, to upscaling, validating and continuously learning throughout a person's career.
Cross-border committees such as the Tornedal Council, Bothnian Arc Committee, Provincia Bothniensis and North Calotte council, all work with facilitating cooperation across the border. The influence skills supply in several indirect ways. The cooperate with regional and municipal authorities in assessing labour needs according to the performance of different industries and sectors. They participate in INTERREG projects and other funding projects, which facilitate knowledge exchange, and they lobby within and outside the region.

\subsubsection{Validation}

An important issue of skills governance is validation of educational degrees obtained by immigrants in foreign countries when moving to the Bothnian Arc. According to a researcher "we are very close minded about it" and argues that immigrants should be able to work within the same professional field even if they have to be downgraded, but then use the experience to catch up. For instance, "a doctor could be hired in the hospital to do basic tasks, and then gradually build the network, learn the specific requirements of the profession in the country and gradually climb up to a better position". According to Nordisk Kompetens, this suggestion makes sense, since there are "nurses that spend much of their time doing basic tasks, like measuring temperature or cleaning, which are tasks that could be taken over by someone without an education". This could both let nurses or any other professional focus on what they are most specialised in while giving opportunities for others to learn from the profession. More generally, the researcher add that "today in Sweden it is really hard to get integrated in the labour market as a foreigner, especially those from outside of the Nordic countries - and we know that getting a job is one of the most effective ways of becoming integrated in society". Therefore, more strategic actions could be done to use foreigners' competences to fill the gaps in the demand, while better integrating them to society. 


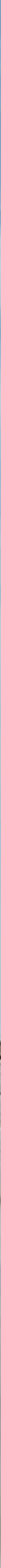




\section{Discussion \& conclusions}

This study has examined different factors at play in the development, supply, demand, and governance of skills in the Bothnian Arc region. Thriving societies, economies, and individuals depend on a solid skills base. This means that possessing the right skills, being able to retain and use them is crucial for securing the long-term development and competitiveness of the region. However, rapidly changing societies and economies are challenging the need for certain skills, and the way we develop and govern them. The findings of this study can be synthesised around three key intertwined themes: (1) supply and demand; (2) roles in skills' development and management; (3) labour mobility and integration of cross-border labour markets.

\section{Supply and demand}

The supply of skills depends on multiple factors, both from the supply and from the demand side. Additionally, the links or missing links between employers and jobseekers play an important role in facilitating the match between the supply and the demand.

Labour supply in general is heavily affected by demographic trends. The Bothnian Arc region is exposed to three important demographic challenges: population decline, ageing, and urbanisation. While some parts of the region, namely Luleå, Oulu and Kempele experience a moderate population increase, the counties as a whole will decline by around $8 \%$ in the course of 20 years. A combination between emigration and low natural increase is leading to a major trend towards ageing population. This will have a substantial impact on the labour market as a high share of the economically active population will retire in the coming years. Finally, population change is asymmetric, with growth being mainly concentrated in the region's urban areas, while small towns and rural areas will be the most affected of population decline.

Moreover, technological innovations, automation, the green transition among other megatrends, are fundamentally challenging the ways economies and societies are organised today. This structural transformation has concrete repercus- sions on the labour markets. Technological and other trends influence the demand for different types of skills with new skills becoming relevant and some of the existing skills becoming obsolete. In the Bothnian Arc region, automatization is not a new phenomenon, technological progress has replaced hand labour with machines over the decades in different waves. This has been more noticeable in the largest industries in the region, such as mining, steel and metal, and pulp-and-paper processing industry. Automation is not a negative development as such, as it secures the competitiveness of the local industries, generates new opportunities for high skill jobs, and releases labour to be absorbed by other sectors. However, it leads to both a vertical and a horizontal mismatch between the skills supply and demand. This means that many workers, do not have the sufficient qualifications to carry out more complex tasks within the same industries, while at the same time their skills may not be useful in other sectors. The demand for skills is geographically asymmetrical, certain municipalities are more reliant to technological innovations than other, depending on their business base. Instead, many areas lack labour, not the most skilled, but those in basic sectors as in construction, education and healthcare.

The speed of transformation of the labour markets is a challenge in itself, which makes it hard for the education system, and those receiving education and training to keep up with the change. This transformation also generates a horizontal mismatch, with an increasing labour demand in emerging sectors such as IT and tourism, but not enough people educated for these types of work. While this is not surprising, as supply eventually follows the demand, the relative remoteness of the region represents a disadvantage when recruiting professionals from outside. In particular when recruiting IT professionals which are on a high demand everywhere in the Nordic countries and the world. In tourism, there is a challenge with the seasonal character of the industry, which does not offer a stable income to workers, leading to a large rotation of people involved in these activities every season. 
The distribution of formal qualifications is also age dependent. Younger generations possess higher education qualifications than older generations in general. This also corresponds to the structural transformation of the labour market where jobs in the region have traditionally been offered in primary or secondary sectors, while today the number of jobs in the tertiary sector is rapidly taking over, with more people employed in services than industry in Luleå and Oulu. There is also a gender imbalance, particularly in Norrbotten, as women show higher levels of education attainment and, thus tend to opt more for the public sector jobs (mainly education and health) or emigrate.

The mismatch between supply and demand is also the result of skills governance and, particularly, the relationship between education and labour market actors. This is addressed in the following section.

\section{Roles in skills development and management}

Structural changes in the labour market require actions from various different players in adapting to the new conditions. On the one hand there are authorities (including educational institutions) responsible for defining education curricula, the number of graduates that are aimed for in each profession, and the overall framework for education. On the other hand, there are employers, who are interested in employees that can perform their work tasks according to the current needs. Additionally, there are actors focusing on regional development, who are concerned about having the necessary skills to ensure the region's economic sustainability and competitiveness. In between there are many actors that emerge. Matching the skills supply and demand increasingly depends on the degree to which these actors can come together and carry out the necessary actions to adapt to the emerging needs.

While the education system remains the most important player in delivering the foundational skills in society, there is an increasing role of employers and multi-actor collaborations in generating professional skills and life-long learning opportunities. There is also more pressure on individuals to be more active in updating their skillsets, but there are also more opportunities for self-learning.

Continuous professional development or lifelong learning is gaining attention as a way to keep up to date with new knowledge and skills throughout working life. Lifelong learning can oc- cur through formal education and accreditation, or through more informal work-based training, to self-learning. Today, academic education tends to be organised in a more rigid frame, with predefined programmes with few opportunities for combining it with work. Adult education provides a variety of opportunities for active professionals to update or gain new skills tailored to their specific needs. Adult education as well as vocational education provide an arena where labour market actors and education actors often team up to deliver different sets of skills directly connected to the practical needs, and the companies' demands. The Swedish-Finnish high school (Svefi) is a particular example of a folk high school where high-school students and adults can tailor an education according to their specific needs or in collaboration employers.

Workplace learning appears to be the most direct way to influence employee's professional development during the working life. In contrast to formal education, workplace training is rarely carried out in a systematic way but is rather sporadic and learning-by-doing. Ad-hoc initiatives are more common and typically connected to the specific employee's tasks. In a way, workplace learning is more utilitarian, in the sense that it serves the interest of the employer before the interests of the employee. Some of the largest industries, which require highly technical skills are said to provide employees with more rigorous training. However, most other companies and employers do not have established systems for training. The same is true within the public sector, where learning opportunities are often detached from the work tasks, with few exceptions such as the medical professions.

In between educators and employers there is a range of actors who play their part in skills development and skills governance. Employment services are key players focusing mainly on bringing people to work and addressing any possible barrier that can enable them to be economically active. There are business associations, and chambers of commerce, mostly advocating for companies' interests, among other things securing their access to skilled workers. They also follow trends that inform what skills are in need, as well as they participate in recruiting, promoting the region, delivering specialised training, and networking opportunities. There are also other public companies, agencies, employment consultancy firms, and research teams that intervene in skills creation, facilitation, or lobby. 
However more implicit forms of skills creation and circulation occur in the intersection of different sectors and actors, and across social and professional networks. This evolves through the interaction between professionals who share information and co-create new knowledge either formally through projects and joint ventures or informally through conferences and social gatherings. For instance, the universities in the region have generated an important ecosystem of skills creation and circulation; not only through education itself, but through research and development. Companies work in close collaboration with universities in developing new technologies and researching the markets. Also, universities often participate in international programmes and projects with EU funding such as HORIZON 2020, INTERREG and Erasmus. The Arctic Five collaboration is a particular example of skills circulation amongst academics of five universities in North Finland, Sweden, and Norway. Universities also collaborate with public institutions in generating knowledge to improve policy and strategic planning in the region. A clear example is the regional competence council in Norbotten, where the university, the regional authorities, and the employment services have teamed up to monitor the skills landscape and take informed decisions.

\section{Labour mobility \& integration of cross-border labour markets}

Labour mobility was addressed above from a demographic perspective. As aforementioned, the Bothnian Arc region struggles with emigration, not being able to compensate for all the skills lost. However, this section focuses specifically on the untapped potential for labour mobility within the Bothnian Arc region. Increased integration of the labour markets across the Finnish/Swedish border can be used more strategically to fill some of the skills gaps. Without increasing the inflow of people from outside the region, municipalities in the Bothnian Arc could better complement each other's needs more actively.

This can be done in different ways. Employers already put substantial effort to employ people across borders. This is evidenced in the construction sector, and also in education. Luleå munici- pality seems to be particularly active in recruiting Finnish teachers. However, delivering skills does not necessarily imply physical labour mobility nor employment at all. Companies and employers can attract the skills needed by using distance work or by outsourcing specific tasks or services to companies in other parts of the Bothnian Arc region. For instance, interviewees refered to a company in Raahe has implemented remote office.

Labour market integration, however, seems to be hampered by a mental barrier that exist amongst people on what the neighbouring nation represents. Despite similar climates and landscapes, cultural and linguistical differences prevail. A cross-border identity seems exists to some degree only within the immediate vicinity of the border, at most some $20 \mathrm{~km}$ away from the Torne river in either side. Most people outside this margin do not see themselves as living in a border region and thus are not necessarily aware of the opportunities existing in the neighbouring country. However, while in theory cultural differences imply an equal barrier for Finns and Swedes to move to each other's country, labour mobility in practice is mostly unidirectional from Finland to Sweden. This is mostly explained by Sweden's cultural hegemony over Finland historically, but Finns tend to have more social ties in Sweden as a result of decades of labour migration. What is more, the Covid-19 outbreak and the uncoordinated measures between the two countries, seems to have fuelled old rivalries and baseless stereotypes between the border societies. Therefore, further integration between the communities in both sides of the border is needed to overcome mental barriers.

Moreover, there are also more 'solid barriers' in the way of a cross-border labour market. Particularly the lengthy procedures needed for registering with the social security systems and different tax regimes. Temporary or seasonal jobs are often too short for carrying on the necessary paperwork. Complying with administrative requirements is often perceived as more difficult than it is in practice. Finally, the measures implemented in spring 2020 to contain the covid-19 virus established a solid barrier for the first time in several decades. While these are temporary, they may reinforce the perception of a border. 


\section{References}

Berlina, A. (2018). Cross-border Public Services ( CPS ) Scientific Report - Annex VI Case study report - Bothnian Arc. ESPON. https://www. espon.eu/sites/default/files/attachments/ ESPON CPS 10 Scientific Report Annex VI Bothnian Arc.pdf

Böckerman, P., Haapanen, M., \& Jepsen, C. (2018). More skilled, better paid: Labour-market returns to postsecondary vocational education. Oxford Economic Papers, 70(2), 485-508. https://doi.org/10.1093/oep/gpx052

Bryson, J. (2017). Disciplinary Perspectives on Skill. In J. Buchanan, D. Finegold, K. Mayhew, \& C. Warhurst (Eds.), The Oxford Handbook of Skills and Training. Oxford University Press. https://doi.org/10.1093/ oxfordhb/9780199655366.013.1

Buchanan, J., Anderson, P., \& Power, G. (2017). Skill Ecosystems. In J. Buchanan, D. Finegold, K. Mayhew, \& C. Warhurst (Eds.), The Oxford Handbook of Skills and Training. Oxford University Press. https://doi.org/10.1093/ oxfordhb/9780199655366.013.21

Busemeyer, M. R. (2014). Worlds of skill formation. Cross-national quantitative analysis. In Skills and Inequality Partisan Politics and the Political Economy of Education Reforms in Western Welfare States (pp. 123-174). Cambridge University Press. https://doi. org/10.1017/cbo9781107477650.006

Busemeyer, M. R., \& Trampusch, C. (2019). The Politics of Vocational Training: Theories, Typologies, and Public Policies. In D. Guile \& L. Unwin (Eds.), The Wiley Handbook of Vocational Education and Training (1st ed., p. 608). Wiley-Blackwell.

Cedefop. (2015). Skill shortages and gaps in European enterprises: striking a balance between vocational education and training and the labour market. In Cedefop reference series no. 102. Publications Office of the European Union. https://doi.org/10.2801/042499

Cedefop. (2019). 2018 European Skills Index. European Union. https://doi. org/:10.2801/564143
Cuadrado, A., Lundgren, A., Wøien, M., \& Teräs, J. (2019). Skills Policies - Building Capacities for Innovative and Resilient Nordic Regions. Preliminary Report: Policy and Literature Review. https://www.nordregio.org/research/ skills-policies-building-capacities-forinnovative-and-resilient-nordic-regions/

Ejdemo, T., \& Parding, K. (2018). 51000 anställningar i Norrbotten till och med 2030 - En analys av rekryteringsbehov och rekryteringsproblem med lösningsförslag. In Rapportserie inom Regional förnyelse. Region Norrbotten. https://www.ltu.se/research/ subjects/arbetsvetenskap/Nyheter-ochaktuellt/51-000-nyanstallningar-behovs-iNorrbotten-1.173298

European Commission. (2016). A New Skills Agenda for Europe. Working together to strengthen human capital, employability and competitiveness. https:// eur-lex.europa.eu/legal-content/EN/ TXT/?uri=CELEX:52016DC0381

European Commission. (2019a). Finland Lapland. https://ec.europa.eu/eures/main.jsp?c atld=7500\&lmi=Y\&acro=lmi\&lang=en\&recordL ang =en \& parentld $=\&$ countryld $=F \mid \&$ region $l d=F I 1$ \&nuts2Code $=$ FI1A\&nuts 3 Code $=F I 1 A 3 \&$ mode $=t$ ext\&regionName=Lappi

European Commission. (2019b). Finland Northern Ostrobothnia. https://ec.europa.eu/ eures/main.jsp?catld=7499\&lmi=Y\&acro=lmi\& lang=en\&recordLang=en\&parentld=\&country $I d=F \mid \&$ region $I d=F \mid 1 \&$ nuts 2 Code $=F \mid 1 A \&$ nuts $3 C$ ode $=$ FI1A3\&mode=text $\&$ regionName=Pohjois Pohjanmaa

European Commission. (2019c). Sweden Norrbottens län. https://ec.europa.eu/eures/ main.jsp?catld=2613\&countryld=SE\&acro $=1 \mathrm{mi}$ \&lang=en\&regionld=SEO\&nuts 2 Code $=$ SEO \& \& nuts 3 Code $=$ SE082\& 2 region Name $=$ Norrbotte ns\%201\%C3\%A4n

Giacometti, A., \& Teräs, J. (2019a). Building Economic and Social Resilience in the Nordic Regions. https://doi.org/10.30689/ PB2019:6.2001-3876 
Giacometti, A., \& Teräs, J. (2019b). Regional Economic and Social Resilience: An Exploratory In-Depth Study in the Nordic Countries. Nordregio. https://doi.org/10.30689/ R2019:2.1403-2503

Giacometti, A., Teräs, J., \& Aalto, H. (2019). Social and Economic Resilience in the Bothnian Arc Cross-Border Region (Issue 11). Nordregio. https://doi.org/10.1016/0091-7435(79)90337-2

Haapanen, M., \& Tervo, H. (2012). Migration of the Highly Educated: Evidence from Residence Spells of University Graduates. Journal of Regional Science, 52(4), 587-605. https://doi. org/10.1111/j.1467-9787.2011.00745.x

Haapanen, M., \& Böckerman, P. (2016). More educated, more mobile? Evidence from postsecondary education reform. Spatial Economic Analysis, 12(1), 8-26. https://doi.org/10.1080/17 421772.2017.1244610

Lundgren, A., Cuadrado, A. Wøien, M. Sigurjónsdottir, H. S., Turunen, E., Salenius, V., Teräs, J., Grelck, J. B. G., \& Lundvall, S. (forthcoming). Skills Policies - Building Capacities for Innovative and Resilient Nordic Regions

Kotavaara, N., Kotavaara, O., Rusanen, J., \& Muilu, T. (2018). University graduate migration in Finland. Geoforum, 96(October 2017), 97-107. https://doi.org/10.1016/j. geoforum.2018.07.010

Manyika, J. (2017). Technology and the Future of Work. https://doi. org/10.3362/9781780446615.001

Montt, G. (2017). Field-of-study mismatch and overqualification: labour market correlates and their wage penalty. IZA Journal of Labor Economics, 6(1), 1-20. https://doi.org/10.1186/ s40172-016-0052-x

Muehleman, S. (2019). Measuring Performance in Vocational Education and Training and the Employer's Decision to Invest in Workplace Training. In D. Guile \& L. Unwin (Eds.), 2The Wiley Handbook of Vocational Education and Training (1st ed., pp. 187-206). John Wiley \& Sons.

OECD. (2015). Skills for Social Progress. The Power of Social and Emotional Skills.
OECD. (2017). Getting Skills Right: Skills for Jobs Indicators. OECD Publishing. https://doi. org/10.1787/9789264277878-en

OECD. (2019). OECD Future of Education and Skills 2030: Conceptual learning framework (OECD Learning Compass 2030). https:// www.oecd.org/education/2030-project/ teaching-and-learning/learning/skills/Skills_ for_2030.pdf

OECD. (2020). Strengthening the Governance of the Skills System. Self assessment tool. OECD. https://www.oecd.org/skills/centre-for-skills/ Strengthening_the_Governance_of_Skills_ Systems_Self_Assessment_Tool.pdf

Oliver, D., Yu, S., \& Buchanan, J. (2019). Political Economy of Vocational Education and Training. In D. Guile \& L. Unwin (Eds.), The Wiley Handbook of Vocational Education and Training. Wiley-Blackwell.

Parding, K., \& Berg-Jansson, A. (2017). Conditions for workplace learning in professional work: Discrepancies between occupational and organisational values. Journal of Workplace Learning, 30(2), 108-120. https://doi. org/10.1108/JWL-03-2017-0023

Pareliussen, J. K. (2016). Age, skills and labour market outcomes in Finland (No. 1321; OECD Economics Department Working Papers). https://doi.org/10.1787/5jlv23953gq1-en

Randall, L., Ormstrup Vestergård, L., \& Wøien Meijer, M. (2020). Rural perspectives on digital innovation: Experiences from small enterprises in the Nordic countries and Latvia. Stockholm. https://doi.org/http://doi.org/10.6027/ R2020:4.1403-2503

Sahlberg, P. (2015). Finnish Lessons 2.0: What can the world learn from educational change in Finland (2nd ed.). Teachers College Press, Columbia University.

Sanchez Gassen, N., \& Heleniak, T. (2019). The Nordic population in 2040 - Analysis of past and future demographic trends. https://doi. org/10.30689/R2019:6.1403-2503 
Skills Panorama. (2019). Skills Panorama glossary. https://skillspanorama.cedefop.europa.eu/en/ glossary/s

Smith, E., \& Teicher, J. (2016). Re-thinking skill through a new lens: evidence from three Australian service industries. Journal of Education and Work, 1-17. https://doi.org/10.10 80/13639080.2016.1243231

Somers, M. A., Cabus, S. J., Groot, W., \& van den Brink, H. M. (2018). Horizontal Mismatch Between Employment and Field of Education: Evidence From a Systematic Literature Review. Journal of Economic Surveys, O(O), 1-37. https://doi.org/10.1111/joes.12271

Statistics Finland. (2019a). Population projection 2019: Population 31 Dec by Area, Year, Sex, Age and Information retrieved from http://pxnet2. stat.fi/PXWeb/pxweb/en/StatFin/StatFin_. vrm__vaenn/statfin_vaenn_pxt_128v.px/table/ tableViewLayout1/
Statistics Finland. (2019b). Population aged 15-74 by labour force status by year and region.

Statistics Sweden. (2020). Population size, number of birth, deaths and migration by region, sex and age. Year 2020 - 2070

Toner, P. (2011). Workforce Skills and Innovation. An Overview of Major Themes in the Literature (No. 55; Education Working Papers, Issue 55). https://doi.org/10.1787/5kgk6hpnhxzq-en

Vandeplas, A., \& Thum-Thysen, A. (2019). Skills Mismatch and Productivity in the EU. In European Economy Discussion Papers. Publications Office of the European Union. https://doi.org/10.2765/954687

World Economic Forum. (2018). The Future of Jobs 2018. In Executive Summary. https://doi. org/10.1177/1946756712473437 
Interview List: Field Study carried in October 2019

\begin{tabular}{|c|c|}
\hline \multicolumn{2}{|c|}{ Cross-border experts } \\
\hline Affiliation & Name / position \\
\hline $\begin{array}{l}\text { Bothnian Arc } \\
\text { Association }\end{array}$ & Heikki Aalto, CEO \\
\hline $\begin{array}{l}\text { North Calotte } \\
\text { Cross-Border Advise } \\
\text { Service }\end{array}$ & Birgitta Tamminen \\
\hline $\begin{array}{l}\text { Nordic Council } \\
\text { of Ministers, } \\
\text { Free Movement } \\
\text { Committee }\end{array}$ & Claes Håkansson \\
\hline $\begin{array}{l}\text { Svefi: Swedish- } \\
\text { Finnish learning } \\
\text { centre - (vocational } \\
\text { and adult education) }\end{array}$ & Göran Mukka \\
\hline Tornedal Council & Tuula Ajanki, CEO \\
\hline
\end{tabular}

\begin{tabular}{|c|c|}
\hline \multicolumn{2}{|c|}{ North Sweden experts } \\
\hline Affiliation & Name / position \\
\hline $\begin{array}{l}\text { EURES Adviser/ Public } \\
\text { Employment Service }\end{array}$ & Monica Mikaelsson \\
\hline $\begin{array}{l}\text { Luleå Technical } \\
\text { University (LTU) }\end{array}$ & $\begin{array}{l}\text {-Karolina Parding } \\
\text {-Saila Piippola }\end{array}$ \\
\hline Luleå city & $\begin{array}{l}\text { Viktor Kåreborn, } \\
\text { Inclusion Strategist }\end{array}$ \\
\hline $\begin{array}{l}\text { Luleå Näringsliv } \\
\text { (business } \\
\text { organisation) }\end{array}$ & Isak Utsi \\
\hline $\begin{array}{l}\text { Norrbotten Chamber } \\
\text { of Commerce }\end{array}$ & Robert Forsberg \\
\hline Norrbotten Region & $\begin{array}{l}\text {-Eva Jonsson } \\
\text {-Kristin Bergwall }\end{array}$ \\
\hline Nordisk kompetens & $\begin{array}{c}\text {-Jonny Häggström } \\
\text {-Anna Katarina } \\
\text { Degerman }\end{array}$ \\
\hline
\end{tabular}

\begin{tabular}{|c|c|}
\hline \multicolumn{2}{|c|}{ North Finland experts } \\
\hline Affiliation & Name / position \\
\hline Business Oulu & Maja Terning \\
\hline $\begin{array}{l}\text { Employment } \\
\text { agency of Northern } \\
\text { Ostrobothnia (ET } \\
\text { centre) }\end{array}$ & Jouni Korhonen \\
\hline Lapland University & $\begin{array}{l}\text { Mirva Juntti, Head } \\
\text { of Partnership and } \\
\text { Business Services }\end{array}$ \\
\hline $\begin{array}{l}\text { Northern } \\
\text { Ostrobothnia } \\
\text { Business Association } \\
\text { (Pohjois-Pohjanmaan } \\
\text { Yrittäjät) }\end{array}$ & $\begin{array}{l}\text { Marjo Kolehmainen, } \\
\text { CEO }\end{array}$ \\
\hline $\begin{array}{l}\text { Oulu Chamber of } \\
\text { Commerce }\end{array}$ & Maria Juurikka \\
\hline Oulu city & $\begin{array}{c}\text { Kyösti Oikarinen, } \\
\text { Chair of the City } \\
\text { Board }\end{array}$ \\
\hline Oulu University & $\begin{array}{c}\text {-Alexandra Middleton } \\
\text {-Eeva-Kaisa Prokkola } \\
\text {-Helena Louhela } \\
\text {-Jaakko Simonen } \\
\text {-Niina Kotavaara } \\
\text {-Mervi Heikkinen }\end{array}$ \\
\hline $\begin{array}{l}\text { Public employment } \\
\text { service, city of Kemi }\end{array}$ & $\begin{array}{c}\text { Hanna Alila, Project } \\
\text { Manager }\end{array}$ \\
\hline $\begin{array}{l}\text { Regional council } \\
\text { of Northern } \\
\text { Ostrobothnia }\end{array}$ & $\begin{array}{c}\text { Tiina Rajala, } \\
\text { Development } \\
\text { Director }\end{array}$ \\
\hline
\end{tabular}




\section{(1I) Nordregio}

P.O. Box 1658

SE-111 86 Stockholm, Sweden

nordregio@nordregio.org

www.nordregio.org

www.norden.org

ISBN 978-91-87295-27-0

ISSN 1403-2503

DOI: http://doi.org/10.6027/R2020:10.1403-2503 